Sharif University of Technology
Scientia Iranica
SCIENTIA
I RAN I CA
http://scientiairanica.sharif.edu

\title{
Seismic behaviour assessment of eccentrically split-X braced frames
}

\author{
R. Sheikhi Garjan and N. Fanaie* \\ Department of Civil Engineering, K. N. Toosi University of Technology, Tehran, Iran. \\ Received 26 April 2018; received in revised form 24 October 2018; accepted 9 March 2019
}

\author{
KEYWORDS \\ Eccentrically split-X; \\ Link beam; \\ Incremental dynamic \\ analysis; \\ Response modification \\ factor; \\ Fragility curve.
}

\begin{abstract}
Eccentrically Braced Frames (EBFs) are lateral resisting systems with appropriate ductility and strength against earthquakes. An important type of such systems, recommended by Popov and also presented in American Institute of Steel Construction (AISC), is eccentrically split-X bracing. The axial force applied to the beam outside the link beam is reduced causing improvement in the behaviour of this type of bracing. In this research, for the first time, the ductility factor, overstrength factor and response modification factor of eccentrically split-X braces are investigated through nonlinear static and incremental dynamic analyses and fragility curves are presented for different ratios of link beam length to span length. For this purpose, three buildings, 2-, 6- and 10-storey structures with the ratios of link beam length to span length $(e / L)$ of $0.05,0.1,0.15$, and 0.2 are considered. The ductility factor of $R_{\mu}=3.55$, overstrength factor of $R_{s}=2.31$ and response modification factor of $R_{L R F D}=8.06$ are calculated under 10 earthquake records. It is concluded that the most appropriate values of $e / L$ ratio in the eccentrically split-X bracing are 0.1 for tall structures and 0.05 for small ones. According to the log-normal distribution, the fragility curves are also plotted considering Collapse Prevention (CP) and immediate occupancy (IO) performance levels.
\end{abstract}

(C) 2021 Sharif University of Technology. All rights reserved.

\section{Introduction}

At present systems resistant to earthquake-induced lateral forces are used in buildings to withstand such forces. One of these systems is called Eccentrically Braced Frames (EBFs).

Much research s was performed by the scientists of the University of California at Berkeley on the seismic behaviour of EBFs in 1970-1990 [1-6], evaluating these systems in real and scaled forms [7-9]. The universities of Nevada [10,11], California [12] and Texas [13-16]

\footnotetext{
*. Corresponding author. Tel.: +982188779623
} E-mail address: fanaie@kntu.ac.ir (N. Fanaie)

doi: $10.24200 /$ sci. 2019.50655 .1804 have also conducted some experimental tests on link beams.

The recent investigations performed by the researchers showed that EBFs can provide significant elastic stiffness, and most particularly in cases of small link beam, compared with special concentrically braced frame and ordinary concentric brace frame bracing systems. If the connection length is not too short, then ductility and energy dissipation capacity will be excellent in the inelastic deformation and comparable to steel moment resisting frame.

Okazaki et al. in 2005 [17] studied steel link beams subjected to cyclic loading and assessed their performances through a sum of 23 tests. Chao et al. at 2006 [18] investigated the web failure, observed earlier in the experiments, using computational simulation. 
Rossi and Lombardo in 2007 [19], studied the effects of overstrength factor on the seismic behaviour of EBFs, designed according to the capacity based design method. Ozhendekci and Ozhendekci in 2008 [20] performed numerical investigations to evaluate the effects of the geometry of EBF on their weights and inelastic behaviours. For this purpose, they designed $420 \mathrm{EBF}$ with short link beams, 105 with medium link beams and 105 with long link beams.

Chegenia and Mohebkhah in 2014 [21], by examining the three long link beams that were modeled on ABAQUS, showed that, although the rotation in the long link beam was limited to 0.02 , using mid stiffeners provides the benefits of long link beams in terms of architecture.

Kurdi et al. in 2017 [22] conducted some experiments on the residual stresses of link beams and showed that the highest tensions occur in certain areas, called K. They showed that the effects of residual stress can be reduced using appropriate horizontal and vertical stiffeners and the link beam performance can be improved.

Ming and Mingzhou in 2017 [23], by examining the eccentric brace with a vertical link beam, which was tested on two samples with a scale of 1 to 2 , concluded that the structure weight is considerably reduced using a high-strength steel in beams and columns. They concluded that the use of ordinary steel for link beams provides the necessary ductility for the structure and greatly affects the energy absorption.

Tian et al. in 2018 [24] examined a 3-storey building with a K-shaped eccentric brace scaled 1 to 2 and concluded that the link beams were the weakest part of the lateral force system of the structure. Based on their research, using high-strength alloy (K-HSS$\mathrm{EBF}$ ) in the beam, can greatly reduce the energy input to the structure.

Bosco and Rossi [25] in 2008 studied the effects of overstrength factor on the design of EBF. Different bracing arrangements are used in EBF.

Brunesi et al. in 2016 [26] attempted to model connecting a beam to a column in high-rise megabraced frame-core buildings with zero length element in OpenSees, and Bosco et al. in 2016 [27] investigated the effect of a fatigue wedding gusset plate of an industrial liquid tank supporting structure with braced frame systems within the open source finite element platform; OpenSees.

One of these arrangements has been recommended by Engelhardt and Popov, and also presented in American Institute of Steel Construction (AISC), (ANSI/AISC 341-05) [28] Figure 1. Such arrangement results in the optimum design of a link beam by reducing or eliminating its axial force. It is worth mentioning that the split-X EBF investigated in this study has a significant difference compared to the

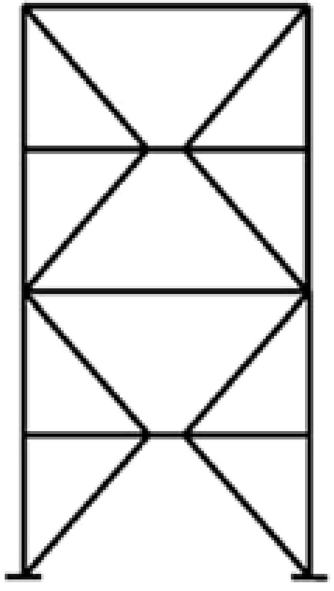

Figure 1. The arrangement of 2-storey eccentrically split-X bracing (ANSI/AISC 341-05) [28].

common eccentrically chevron $\mathrm{V}$ and inverse $\mathrm{V}$ braced frames, causing it to display different behaviour. The reason behind this, is the decrease in axial force of the beam outside the link beam as well as the increase in shear force in the link beam of the split-X EBF in comparison with the usual chevron braced frame. This is due to different signs (tensile and compressive) of the upper and lower braces of the floor and reckoned as a highly desirable phenomenon.

The axial force reduction of the outside link beam the in split-X EBF causes the buckling potential to be diminished for this beam. Thus, the length of it is not short as is the link beam, and more importantly, shear force in the link beam of the split-X EBF increases compared to the usual chevron braced frame under the same conditions. This results in the link beam of the split-X EBF to have a more reliable shear behaviour compared to the conventional eccentric chevron brace, and has a definite shear failure mode. However, no considerable research has been conducted on the mentioned EBF arrangement. So far, no investigation is found on the evaluation of the response modification factor, ductility and overstrength factors of this system. This research focuses on studying and obtaining the response modification factor, ductility and overstrength factors of such a kind of bracing system arrangement, called split-X, using Incremental Dynamic Analysis (IDA).

\section{Eccentrically Braced Frame (EBF)}

The bracing and link beam are designed for appropriate seismic performance of EBF in such a way that under ultimate loading condition, yielding the link beam prevents the bracing from buckling. For insurance, the ultimate capacity of the link beam is evaluated precisely and EBF is designed in such a way to occur inelastic deformation in the link beam under severe 


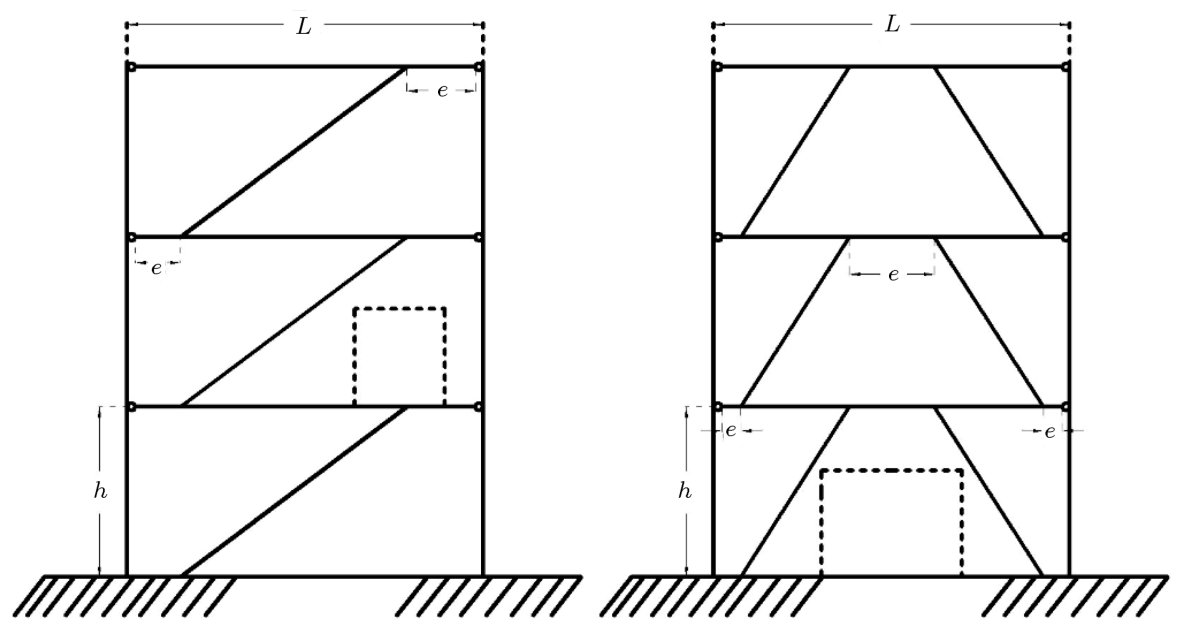

Figure 2. Ordinary Eccentrically Braced Frames (EBFs) [18].

seismic loading. Also, the link beams act as structural fuses which prevent the braces from buckling. Figure 2 presents the ordinary EBFs [18].

The important factor in controlling the behaviour of a link beam is its length. Short link beams are yielded in the shear, long ones in the bending moment, and medium in the combination of shear and bending moment. The performance and energy absorption of short link beams is more appropriate compared with medium and long ones. The following steps are considered in the design of EBF systems [28]:

a) Estimating the shearing capacity needed for a link beam and selecting the sections;

b) Designing other elements in such a way that a structural fuse can be created in the link beam;

c) Estimating demand ductility for the structure and determining the details necessary for the link beam.

\section{Incremental Dynamic Analysis (IDA)}

The intrinsically random nature of earthquakes is one of the main uncertainties in assessing the seismic behaviour of structures. For quantifying such uncertainty, the seismic response of a structure should be determined by performing different dynamic analyses in the course of different earthquake ground motion. In this study, earthquake uncertainty has been considered using IDA. In this regard, sufficient numbers of records are used to consider the uncertainties in the frequency content and earthquake record spectra shapes [29]. Then, each earthquake record is scaled in such a way that can cover appropriate ranges of seismic intensities and also structural responses, from elastic limit to collapse. For IDA analysis, the Intensity Measure (IM) (eg: PGA (Peak Ground Acceleration ) or $S_{a}\left(T_{1}\right)$ ) is scaled with a proper algorithm, starting from a very low amount to a certain level, in order to motivate the elastic response in the considered structural model and target collapse state, respectively. Time history analysis is conducted in IDA, using different records generated by various scale factors. At the end of each analysis, the DM (Damage Measure) values are determined, corresponding to the IM levels, used in dynamic analysis.

For utilizing IDA analysis, selecting appropriate parameters for IM and DM is of greatest significance. The mentioned parameters should be scalable in order to be selected for a suitable seismic intensity. In this study, the spectral acceleration of the first mode is chosen as IM to include the principal period of structure in the scaling and considering earthquake duration and damping parameters. Joint rotation, inter-storey drift, roof displacement and axial deformation of elements can be used as the collapse criteria of structures. In this research, maximum inter-storey drift is considered as DM to achieve an appropriate structural response against earthquake records.

\section{Calculating the seismic parameters of a structure}

The response modification factor is considered in almost all universal codes for reducing the calculated earthquake loads in order to consider inelastic behaviour. This allows the designers to conduct elastic analysis under reduced loads and design structures based on the obtained results. The mentioned factor depends on different aspects, the most important of which are: ductility of structure, material properties, damping characteristics, cooperation of non- structural members, overstrength etc.

In this study, the response modification factor is calculated using Uang's ductility factor method [30], in which real nonlinear behaviour is usually idealized by a bilinear elasto perfectly plastic relation (Figure 3) [31]. 


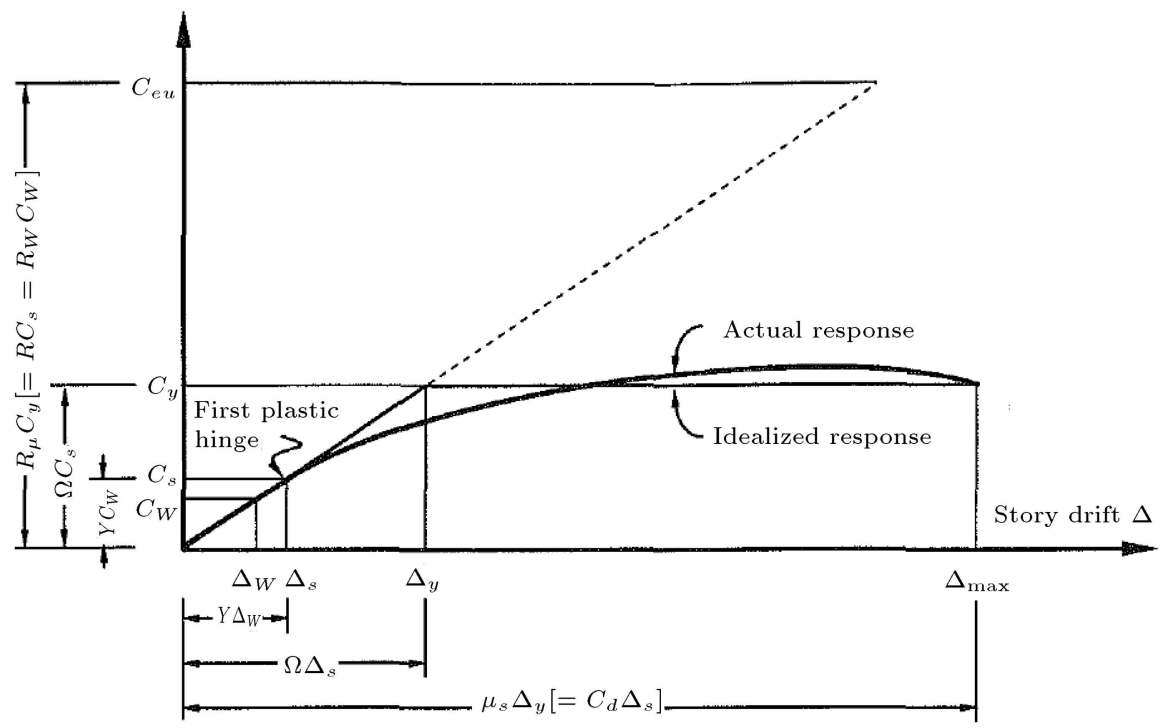

Figure 3. Elastic and inelastic responses of structure [30].

In order to calculate the response modification factor, some parameters are defined using the base shears shown in Figure 3. The first type is overstrength factor. The overstrength phenomenon is important in earthquake occurrence and each frame presents different overstrength under different earthquakes. The overstrength factor is calculated through IDA in this research. Here, the method that is presented by Mwafy and Elnashai [32], is used for computing maximum base shear through IDA. Thus, this involves a structural model subjected to one (or more) ground motion $\operatorname{record}(\mathrm{s})$, each of which is scaled to multiple intensity levels [33]. The overstrength factor is expressed in Eq. (1):

$$
R_{s}=\frac{V_{b(D y n, u)}}{V_{b(s t, y)}}
$$

It means that overstrength is the ratio of dynamic base shear, obtained from mechanism formation and collapse in the structure, to the static base shear corresponding to the first plastic hinge formation. The overstrength factor considers the actual lateral strength of the structure against its design lateral strength.

In the method presented by Mwafy and Elnashai [33], the ductility factor is obtained directly using the results of IDA and linear dynamic analysis as Eq. (2):

$$
R_{\mu}=\frac{V_{b(D y n, e l)}}{V_{b(D y n, u)}} .
$$

In order to obtain $V_{b(D y n, u)}$, the spectral acceleration of the earthquake record (the IM applied in this study) increases to form a mechanism in the structure or meet the considered damage. Basically, such spectral acceleration, which leads to the above mentioned mechanism or damage, is accepted as the ultimate limit, where the corresponded base shear is obtained. Additionally, the maximum linear base shear of the structure is also calculated through dynamic analysis, assuming the elastic behaviour of the structure under the same spectral acceleration. The base shear, corresponding to the first plastic hinge, which has been obtained through nonlinear static analysis, is used for calculating the overstrength factor. It means that the end of the linear zone, corresponding to the first plastic hinge, can be considered the same in both static and dynamic analyses [32]. The ductility factor depends on several aspects including the type of structural system, the quality of connections, number of storeys, etc.

Allowable stress factor $(Y)$ Eq. (3): in the designing codes, $V_{s}$ is reduced to $V_{w}$ through a factor called allowable stress factor, the amount of which is considered as 1.44 in this research [30]:

$$
Y=\frac{V_{s}}{V_{w}} .
$$

In fact the origin of the response modification factor is the strength reduction factor due to ductility $\left(R_{\mu}\right)$ and overstrength factor $\left(R_{s}\right)$. These two factors have already been defined.

The response modification factor with the ultimate strength method is defined as Eq. (4):

$$
R_{u}=\frac{V_{e}}{V_{y}} \times \frac{V_{y}}{V_{s}}=R_{\mu} \times R_{s} .
$$

The response modification factor with the allowable stress design method is expressed as Eq. (5):

$$
R_{w}=\frac{V_{e}}{V_{y}} \times \frac{V_{y}}{V_{s}} \times \frac{V_{s}}{V_{w}}=R_{\mu} \times R_{s} \times Y .
$$




\section{IDA analyses}

For performing IDA, several earthquake records should be selected properly. Regarding the soil type, the stations of these records should be similar to the site in which the structure is located. In this regard, 10 records of globally well-known earthquakes are chosen and presented in Table 1 . Shear wave velocities of the stations are in accordance with those of the soil type II in Iranian standard No. 2800.

An appropriate algorithm should be used for scaling the seismic intensity to optimize the scaling numbers of each record for analyzing, and have sufficient accuracy and velocity for meeting the scale of seismic intensity which causes the failure of the structure. For this purpose, a hunt and fill algorithm has been used in the present research. In this method, for scaling the seismic intensity, first, a very low value $(0.005 \mathrm{~g})$ is selected for the seismic intensity parameter (spectral acceleration of the first mode) which guarantees the linear response of the structure. Then, in the searching step, for finding the range of spectral acceleration of the first mode in which the considered failure has been occurred, the seismic intensity increases at each step, based on the below formula, using the least number of points. Therefore, the value of $S_{a}\left(T_{1}\right)$ at each step is equal to the value of $S_{a}\left(T_{1}\right)$ in the previous step, plus $\alpha$ times the number of its previous step (Eq. (6)). In this study, $\alpha$ is considered as 0.05 .

$$
S_{a}\left(T_{1}\right)_{i}=S_{a}\left(T_{1}\right)_{i-1}+\alpha \times(i-1) .
$$

\section{The studied models}

In this research, 12 eccentrically split-X braced frames are investigated tri-dimensionally, including 2-, 6- and 10 -storey structures with the ratios of link beam length to span length $(e / L)$ of $0.05,0.1,0.15$, and 0.2 . It is assumed that they are located in San Francisco, California (a relatively high seismic region) on soil type D, according to ASCE-7-10. [34].

Regarding the initial response modification factor of $R_{L R F D}=7.5$, the structural components (bracings, beams and columns) are firstly designed. In this design, link beam is considered as a structural fuse. Then, response modification factor has been calculated as 8 using the results of push over analysis based on adaptive push over. This factor is used for designing the main structures.

The structures are designed and analyzed using ETABS Nonlinear v13.1.1 software, which considers the AISC 360-10 code for designing the elements. The applied steel is A992Fy50, the height of all storeys $3.2 \mathrm{~m}$, span lengths $6 \mathrm{~m}$, dead load $400 \mathrm{~kg} / \mathrm{m}^{2}$ and live load $200 \mathrm{~kg} / \mathrm{m}^{2}$.

The distribution of lateral force used in this research is based on the first mode of the structure and an inverted triangle. In the analysis, it is assumed that a vibration mode dominates the behaviour of the whole structure and the corresponding mode shape remains constant during the analysis. This kind of force distribution is used according to the Iranian code for nonlinear static analysis.

All the connections between beam to column as well as the braces to each other are hinge forms on the frame plane. The plans of all storeys are considered the same in the studied structures. Figure 4 presents the plan and locations of braces, in dotted lines. Figure 5 shows the configuration of the frames extracted from a

Table 1. The specifications of the earthquakes records, selected for Incremental Dynamic Analysis (IDA).

\begin{tabular}{|c|c|c|c|c|c|c|c|c|c|c|}
\hline $\begin{array}{c}\text { Record } \\
\text { no. }\end{array}$ & Record & $\begin{array}{l}\text { Record } \\
\text { station }\end{array}$ & $\begin{array}{c}\text { Occurrence } \\
\text { date }\end{array}$ & $\begin{array}{l}\text { PGA } \\
(\mathrm{g})\end{array}$ & Mag. & Mechanism & $\begin{array}{c}R_{j b} \\
(\mathbf{k m})\end{array}$ & $\begin{array}{l}\boldsymbol{R}_{r u p} \\
(\mathbf{k m})\end{array}$ & $\begin{array}{l}\text { Vs30 } \\
(\mathrm{m} / \mathrm{s})\end{array}$ & $\begin{array}{c}\text { Lowest } \\
\text { useable } \\
\text { frequency } \\
(\mathrm{Hz})\end{array}$ \\
\hline 1 & Cape Mendocino & Rio Dell Overpass & $1992 / 04 / 25$ & 0.195 & 7 & Thrust & 7.9 & 7.9 & 312 & 0.07 \\
\hline 2 & Hector mine & Hector & $1994 / 01 / 17$ & 0.318 & 7.13 & Strike slip & 10.35 & 11.66 & 726 & 0.0375 \\
\hline 3 & Imperial valley & Delta & $1979 / 10 / 15$ & 0.237 & 6.53 & Strike slip & 22.03 & 22.03 & 242.05 & 0.0875 \\
\hline 4 & Kobe & Nishi-Akashi & $1995 / 01 / 16$ & 0.370 & 6.9 & Strike slip & 7.08 & 7.08 & 609 & 0.125 \\
\hline 5 & Kocaeli & Arcelik & $1999 / 08 / 17$ & 0.218 & 7.51 & Strike slip & 10.56 & 13.49 & 523 & 0.0875 \\
\hline 6 & Kocaeli & Duzce & $1999 / 08 / 17$ & 0.229 & 7.51 & Strike slip & 13.6 & 15.37 & 281.86 & 0.1 \\
\hline 7 & Loma Prieta & Capitola & $1989 / 10 / 18$ & 0.541 & 6.93 & Reverse oblique & 8.65 & 15.23 & 288.62 & 0.25 \\
\hline 8 & Manjil & Abbar & $1990 / 06 / 20$ & 0.077 & 7.37 & Strike slip & 12.55 & 12.55 & 723.95 & 0.13 \\
\hline 9 & Northridge & Canyon Country & $1994 / 01 / 17$ & 0.318 & 6.69 & Reverse & 11.39 & 12.44 & 325.6 & 0.125 \\
\hline 10 & Superstition & Poe Road & $1987 / 11 / 24$ & 0.446 & 6.54 & Strike slip & 11.16 & 11.16 & 316.64 & 0.1625 \\
\hline
\end{tabular}




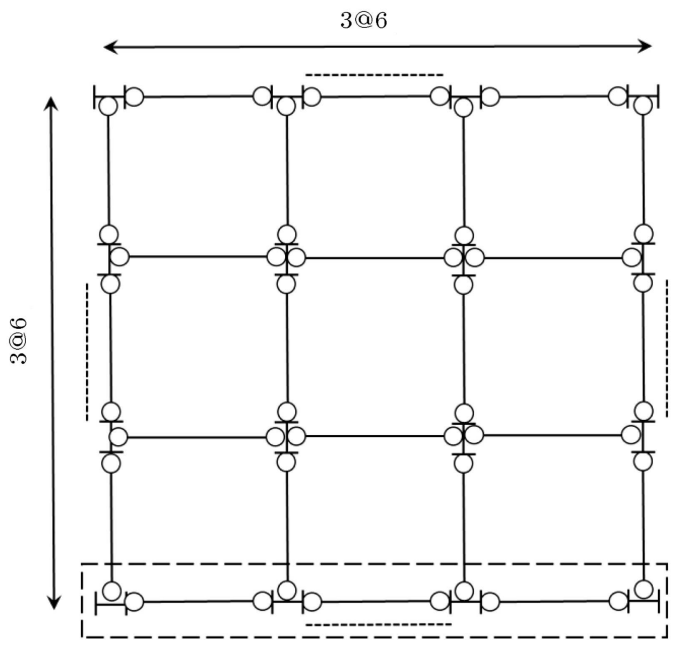

Figure 4. Plan of the studied structures.

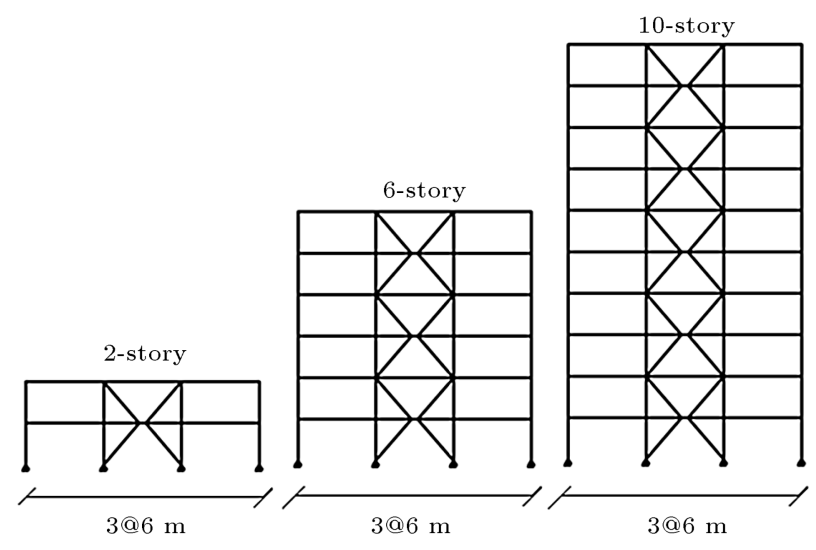

Figure 5. The configuration of studied structures.

tri-dimensional structure. Plate girders have been used for link beams of braced spans for controlling the unbalanced tension and compression axial forces. Tables $2-5$ present the properties of structural components in the studied frames.

\section{Modeling in OpenSees software}

In this research, OpenSees [35] software has been used for modeling and performing nonlinear static and time history dynamic analyses. This software, produced by the University of California, Berkeley, is one of the strongest software available for nonlinear and dynamic analyses using fiber elements. A nonlinear beam column element with control of displacement has been used to model the columns, bracings and beams in this software.

This element can take into account the effects of P-delta and large deformations for considering the geometric nonlinear effects. In order to model the distributed plasticity of elements in the OpenSees program, the sections of each element (beams, columns, and bracings) are divided into several fibers (120 fibers for flange and web cross sections). These elements are divided into several segments in their lengths as well. Moreover, steel materials are modeled using a uniaxial material hysteretic behaviour model which can model the behaviour of steel in tri-linear forms in compression and tension. By this behaviour curve, the points of yielding, failure and buckling of each element can be presented to the program. The slope of strain hardening of steel under tension has also been considered as $2 \%$ of the slope of the elastic region. Also, for modeling damping, Rayleigh damping is used, in which parameters $\alpha$ and $\beta$ are calculated based on the period of each structure. For geometric transformation, a P-delta transformation command is used for braces and columns and a Corotational command for beams. A zero-length element has been used in the connection of beam to column as well as bracing to beam and column for modeling hinge connections of the frame elements. The nodes are constrained in the hinge connection location only in the degrees of freedom of translation. The storey mass is considered as a

Table 2. The sections used in the 2-storey frame.

\begin{tabular}{ccccccc}
\hline Storey & Side columns & Middle columns & Bracing & Side beams & Beam outside link beam & Link beam \\
\hline 2 & W6x12 & W $5 \times 16$ & 2 C5x6.7 & W12x19 & PG2-1 & PL2-1 \\
1 & W6x12 & W5x16 & 2 C6x 8.2 & W12x19 & PG2-1 & PL2-1 \\
\hline
\end{tabular}

Table 3. The sections used in the 6-storey frame.

\begin{tabular}{|c|c|c|c|c|c|c|}
\hline Storey & Side columns & Middle columns & Bracing & Side beams & Beam outside link beam & Link beam \\
\hline 6 & W6x12 & W5x16 & $2 \mathrm{C} 4 \times 5.4$ & $\mathrm{~W} 12 \times 19$ & PG6-3 & PL6-3 \\
\hline 5 & W6x12 & W5x16 & $2 \mathrm{C} 6 \times 8.2$ & W12x19 & PG6-3 & PL6-3 \\
\hline 4 & W6x12 & $\mathrm{W} 8 \mathrm{x} 40$ & $2 \mathrm{C} 5 \mathrm{x} 9$ & $\mathrm{~W} 12 \times 19$ & PG6-2 & PL6-2 \\
\hline 3 & W4x13 & $\mathrm{W} 8 \mathrm{x} 40$ & $2 \mathrm{C} 7 \times 9.8$ & W12x19 & PG6-2 & PL6-2 \\
\hline 2 & $\mathrm{~W} 5 \times 16$ & $\mathrm{~W} 18 \times 86$ & $2 \mathrm{C} 7 \times 9.8$ & W12x19 & PG6-1 & PL6-1 \\
\hline 1 & W5x16 & W18x86 & $2 \mathrm{C} 6 \times 10.5$ & $\mathrm{~W} 12 \times 19$ & PG6-1 & PL6-1 \\
\hline
\end{tabular}


Table 4. The sections used in the 10-storey frame.

\begin{tabular}{|c|c|c|c|c|c|c|}
\hline Storey & Side columns & Middle columns & Bracing & Side beams & $\begin{array}{c}\text { Beam outside } \\
\text { ink beam }\end{array}$ & Link beam \\
\hline 10 & W6x12 & W5x16 & $2 \mathrm{C} 3 \times 5$ & W12x19 & PG10-5 & PL10-5 \\
\hline 9 & W6x12 & W5x16 & $2 \mathrm{C} 4 \times 7.25$ & W12x19 & PG10-5 & PL10-5 \\
\hline 8 & W6x12 & W8x67 & $2 \mathrm{C} 7 \times 9.8$ & W12x19 & PG10-4 & PL10-4 \\
\hline 7 & $\mathrm{~W} 4 \mathrm{x} 13$ & W8x67 & $2 \mathrm{C} 5 \times 9$ & W12x19 & PG10-4 & PL10-4 \\
\hline 6 & W5x16 & $\mathrm{W} 18 \times 130$ & $2 \mathrm{C} 5 \times 9$ & W12x19 & PG10-3 & PL10-3 \\
\hline 5 & $\mathrm{~W} 5 \mathrm{x} 16$ & $\mathrm{~W} 18 \mathrm{x} 86$ & $2 \mathrm{C} 8 \times 11.5$ & $\mathrm{~W} 12 \times 19$ & PG10-3 & PL10-3 \\
\hline 4 & W5x16 & W14x193 & $2 \mathrm{C} 6 \times 10.5$ & W12x19 & PG10-2 & PL10-2 \\
\hline 3 & W5x19 & W14x132 & $2 \mathrm{C} 9 \times 13.4$ & $\mathrm{~W} 12 \times 19$ & PG10-2 & PL10-2 \\
\hline 2 & $\mathrm{~W} 8 \mathrm{x} 21$ & W14x193 & $2 \mathrm{C} 9 \times 13.4$ & $\mathrm{~W} 12 \times 19$ & PG10-1 & PL10-1 \\
\hline 1 & W6x 25 & W14x193 & $2 \mathrm{C} 9 \times 13.4$ & W12x19 & PG10-1 & PL10-1 \\
\hline
\end{tabular}

Table 5. The properties of the plate girder sections used for the beams in the braced spans.

\begin{tabular}{cccccccccc}
\hline $\begin{array}{c}\text { Plate } \\
\text { girder }\end{array}$ & $\begin{array}{c}\text { Web } \\
\text { height } \\
(\mathbf{c m})\end{array}$ & $\begin{array}{c}\text { Web } \\
\text { thickness } \\
\mathbf{( c m})\end{array}$ & $\begin{array}{c}\text { Flange } \\
\text { width } \\
\mathbf{( c m})\end{array}$ & $\begin{array}{c}\text { Flange } \\
\text { thickness } \\
(\mathbf{c m})\end{array}$ & $\begin{array}{c}\text { Plate } \\
\text { girder }\end{array}$ & $\begin{array}{c}\text { Web } \\
\text { height } \\
(\mathbf{c m})\end{array}$ & $\begin{array}{c}\text { Web } \\
\text { thickness } \\
(\mathbf{c m})\end{array}$ & $\begin{array}{c}\text { Flange } \\
\text { width } \\
(\mathbf{c m})\end{array}$ & $\begin{array}{c}\text { Flange } \\
\text { thickness } \\
(\mathbf{c m})\end{array}$ \\
\hline PG2-1 & 45 & 0.9 & 20 & 0.8 & PL2-1 & 45 & 0.9 & 20 & 0.5 \\
PG6-1 & 45 & 1.1 & 20 & 0.8 & PL6-1 & 45 & 1.1 & 20 & 0.5 \\
PG6-2 & 40 & 0.9 & 20 & 0.8 & PL6-2 & 40 & 0.9 & 20 & 0.5 \\
PG6-3 & 25 & 0.8 & 20 & 0.9 & PL6-3 & 25 & 0.8 & 20 & 0.5 \\
PG10-1 & 45 & 1.4 & 20 & 1 & PL10-1 & 45 & 1.4 & 20 & 0.6 \\
PG10-2 & 45 & 1.3 & 20 & 1 & PL10-2 & 45 & 1.3 & 20 & 0.5 \\
PG10-3 & 45 & 1.1 & 20 & 0.8 & PL10-3 & 45 & 1.1 & 20 & 0.5 \\
PG10-4 & 40 & 0.9 & 20 & 0.8 & PL10-4 & 40 & 0.9 & 20 & 0.5 \\
PG10-5 & 25 & 0.7 & 20 & 0.8 & PL10-5 & 25 & 0.7 & 20 & 0.5 \\
\hline
\end{tabular}
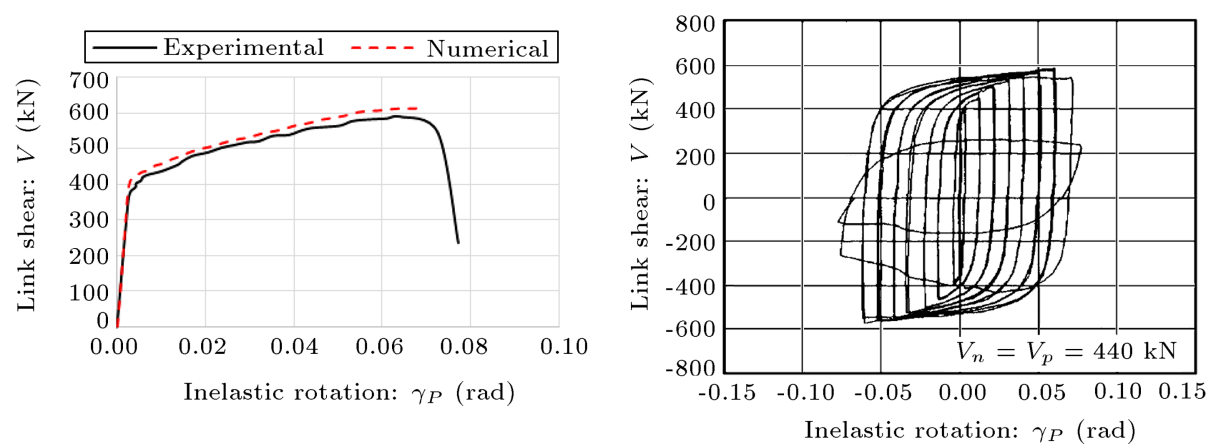

Figure 6. Comparison of the results of finite element modeling of link beam and Okazaki experimental test [17].

lumped mass in the nodes and storey floors as a rigid diaphragm.

The shear behaviour of the link beam has been modeled according to the research by Rozon et al., considering parallel material and a zero length element [36].

For validation of the nonlinear behaviour of link beams due to dynamic analysis, the Okazaki model [17] has been used, which has examined the hysteresis behaviour of the link beam.
Figure 6 compares the results of finite element modeling and experimental testing on the link beam.

The Okazaki experimental study included 12 specimens in which a $W 10 \times 33$ section (with length of $584 \mathrm{~mm}$ ) was used for verifying. The alloy used at this section is ASTM A992 $\left(F_{y}=345 \mathrm{MPa}\right)$. According to the research by Bosco et al. [27], a zero-length element has been used to model the shear behaviour of a link beam in OpenSees software, based on the shear 


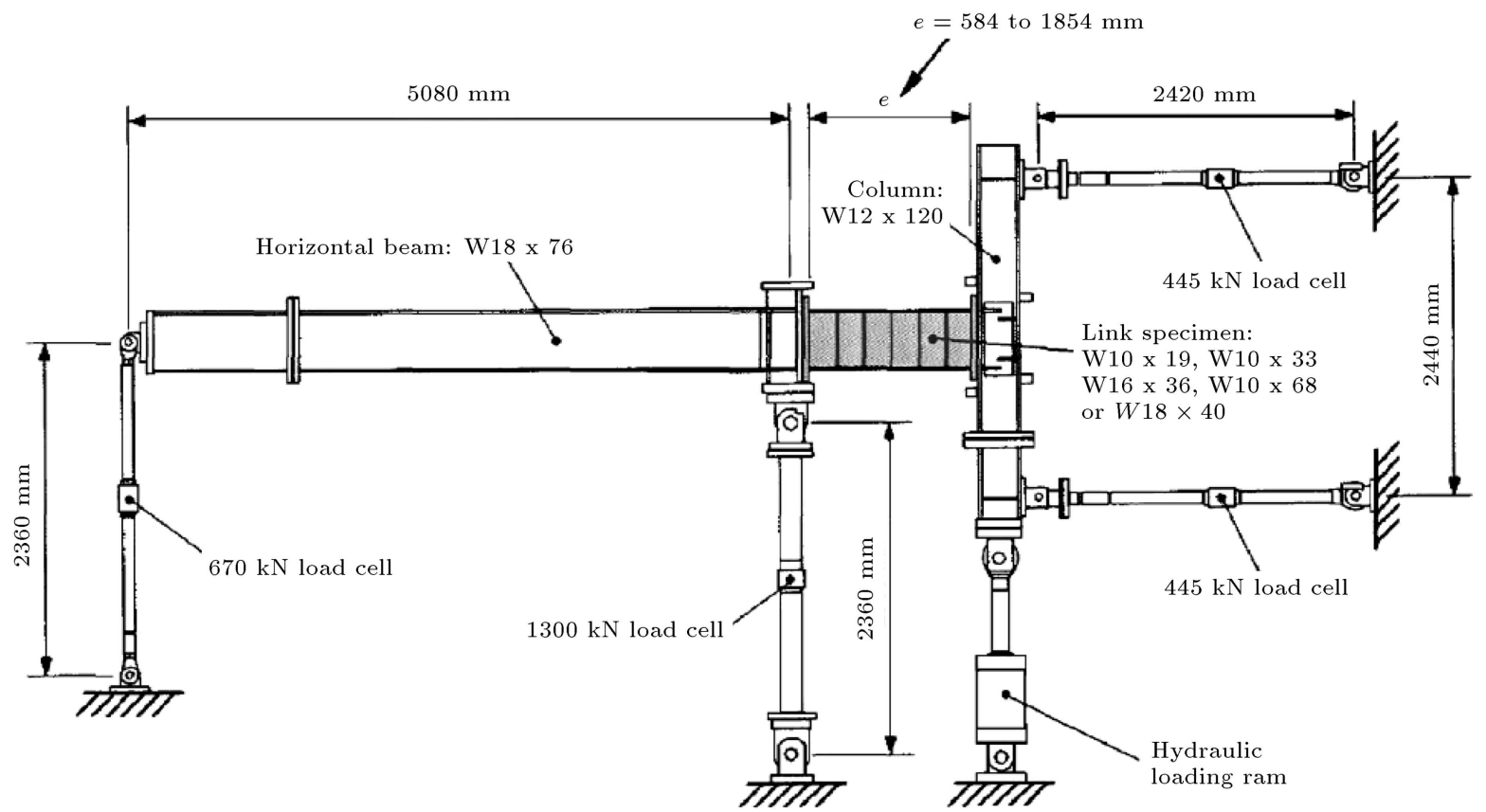

Figure 7. Details of Okazaki experimental test [17].

capacity of each cross section. Figure 7 shows how this experiment is conducted.

\section{The results of analysis}

\subsection{Nonlinear static analysis}

Adaptive push over analysis is used for obtaining the base shear force using nonlinear static analysis. According to the structural failure criteria in ASCE, when the structure meets these criteria, the base shear force is recorded, which is used for calculating the response modification factor of the structure.

Figures 8-10 present the push over curves of the structure for the triangular lateral load pattern.

These figures show that by increasing the number

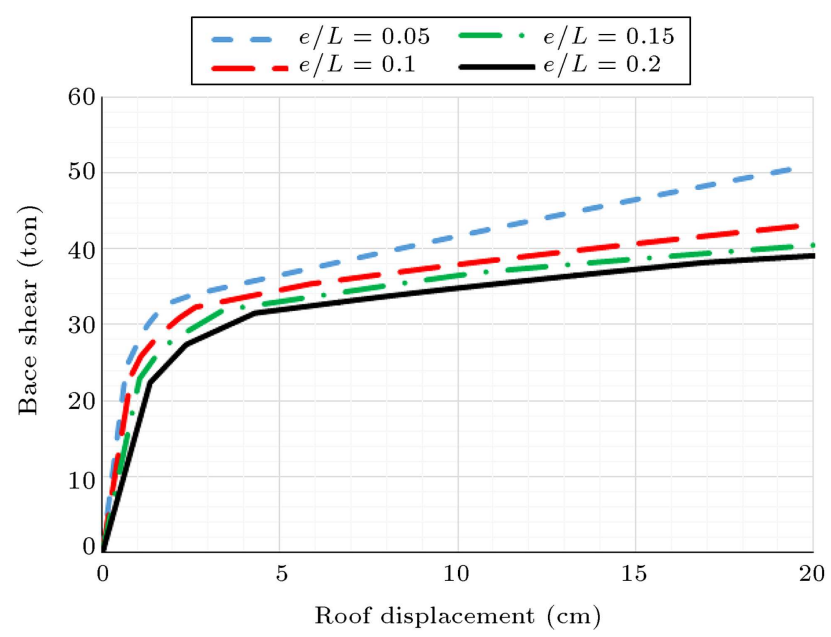

Figure 8. Pushover curves of 2-storey frame. of storeys, the ratio of $e / L$ has more effect on structure stiffness, and when this ratio increases, the stiffness of the structure is reduced. So, in a 10-storey, it is faster than in 2- and 6-storeys.

\subsection{Incremental Dynamic Analysis (IDA)}

Figures 11-22 present IDA curves for the studied frames. All behaviour steps of the structure under earthquake are evident in the curves (from elastic limit to collapse limit).

According to the curves, in general, by increasing the height of structures, the structures enter the nonlinear region sooner. Moreover, IM values are reduced in the curves for a constant value of DM. In the other words, it can be said that $S_{a}$, corresponding to a certain

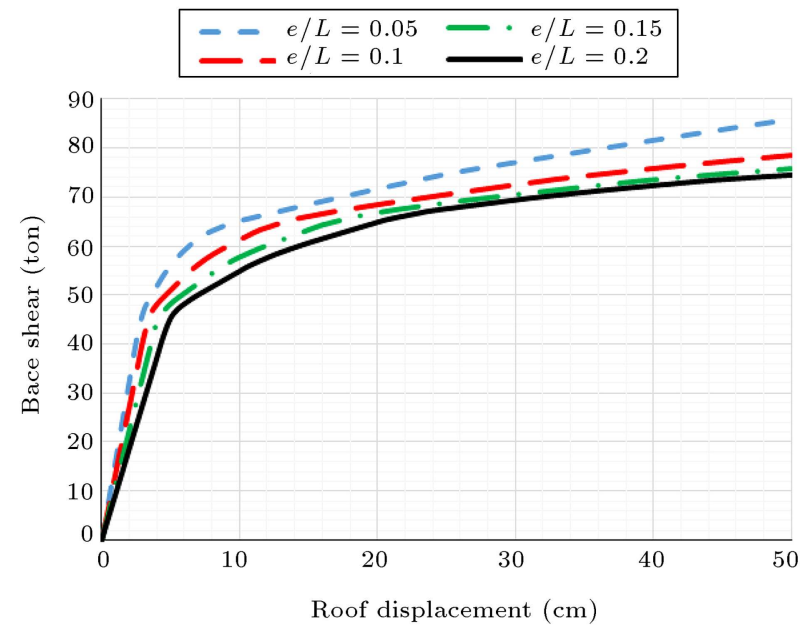

Figure 9. Pushover curves of 6-storey frame. 


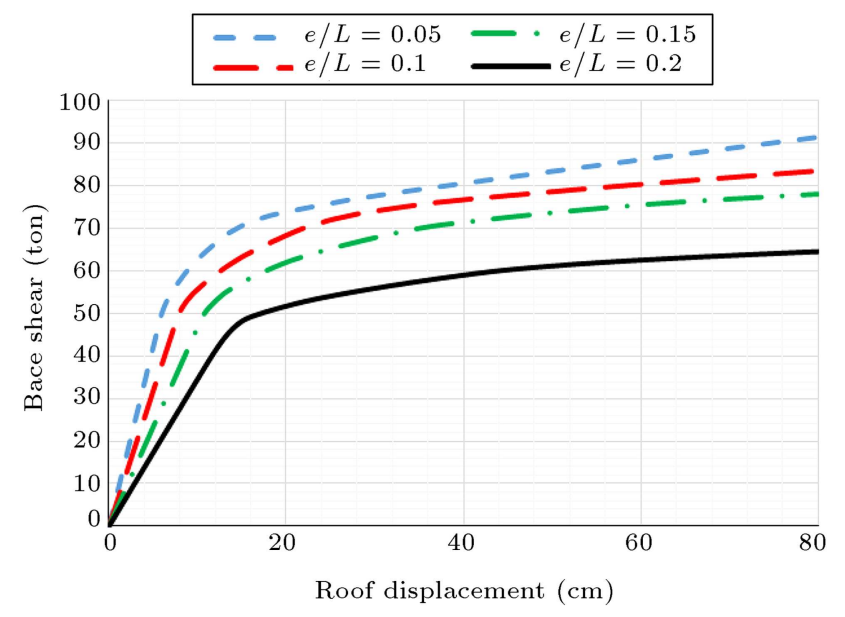

Figure 10. Pushover curves of 10-storey frame.

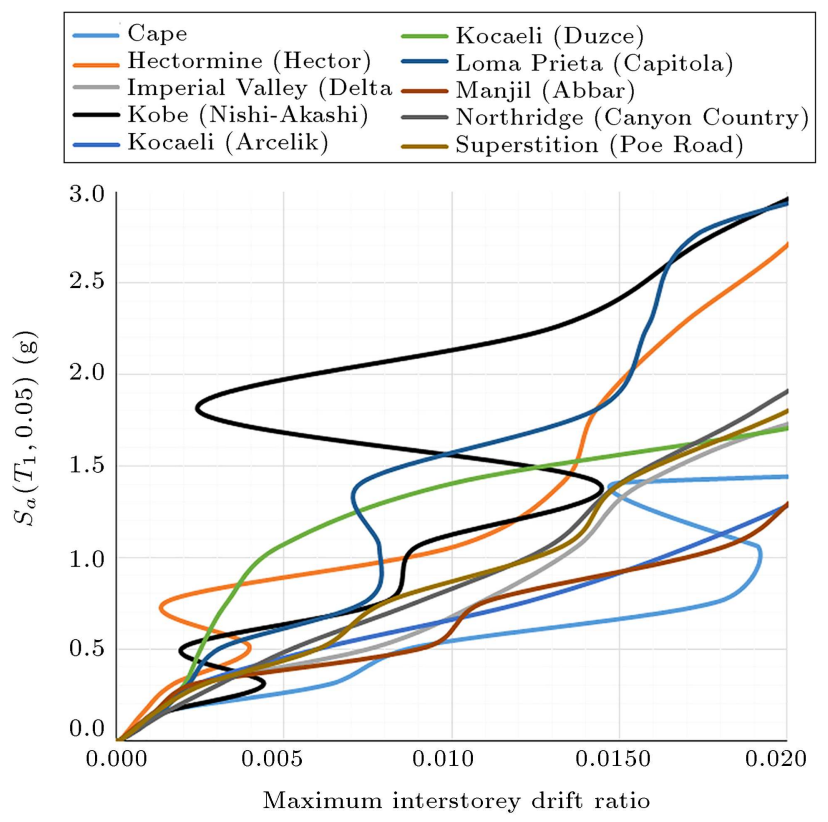

Figure 11. Incremental Dynamic Analysis (IDA) curves for 2-storey structure with $e / L=0.05$.

damage criterion, is reduced by increasing the height of the structure.

\subsection{Calculating response modification factor}

Tables 6-17 present the ductility, overstrength and response modification factors of the studied frames for ultimate state and allowable stress design methods, considering the results obtained from nonlinear static and nonlinear time history dynamic analyses for the selected records, as well as the explanations presented in section 3 of this research.

The values of overstrength, ductility and response modification factors for 2-, 6- and 10-storey frames are summarized and presented in Table 18, versus the ratio of link beam length to span length. Ductility factor, overstrength factor and response modification

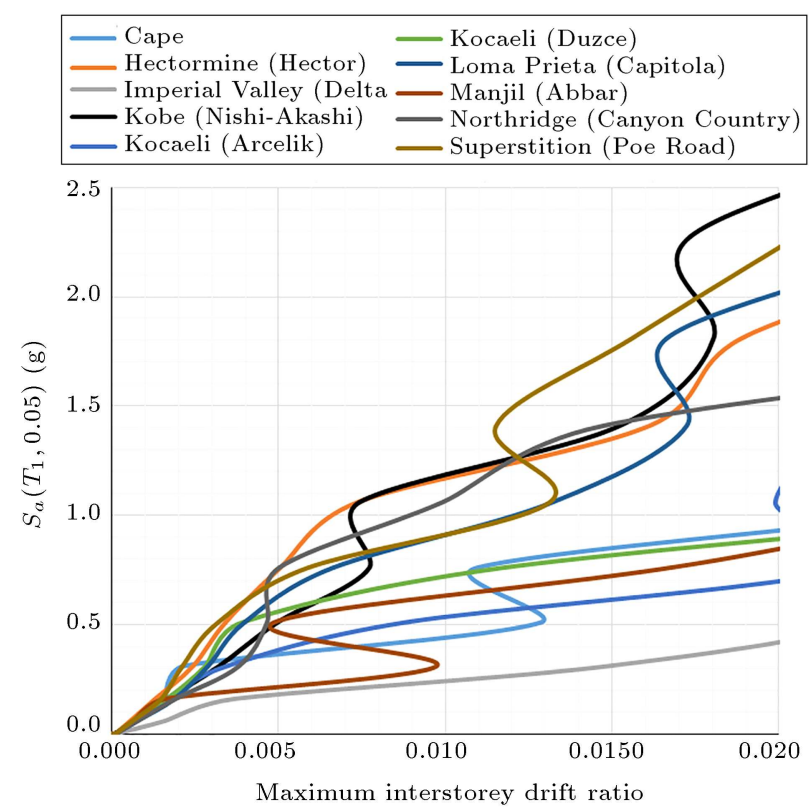

Figure 12. Incremental Dynamic Analysis (IDA) curves for 2-storey structure with $e / L=0.1$.

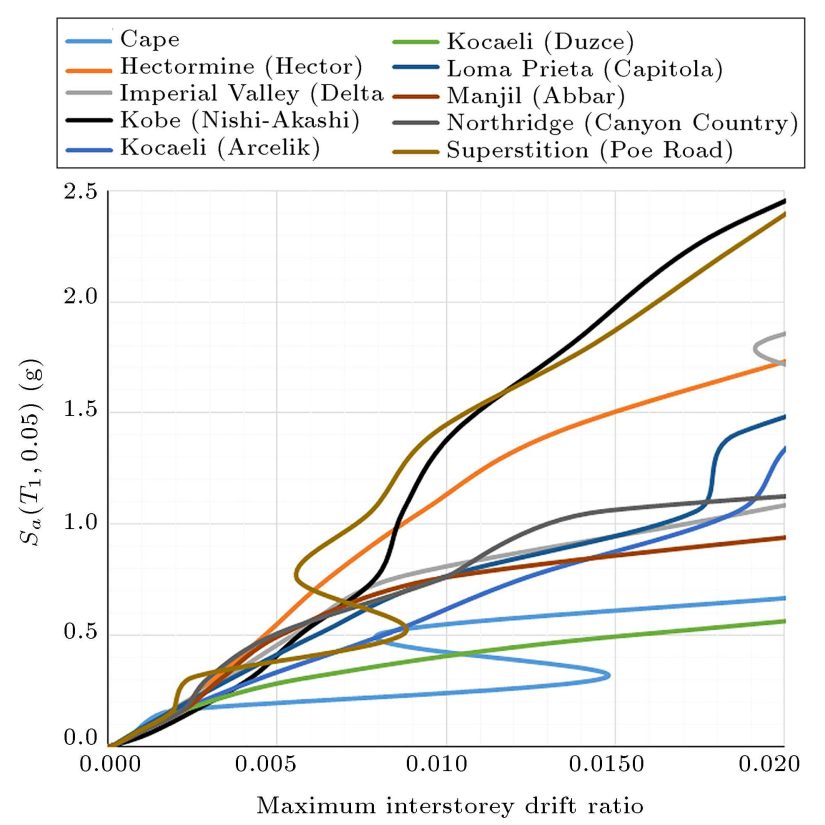

Figure 13. Incremental Dynamic Analysis (IDA) curves for 2-storey structure with $e / L=0.15$.

factor of 2-, 6- and 10-storey structures are presented in Figures 23-25, respectively.

Considering the curves plotted for a 10-storey structure, the ductility factors are higher for each ratio of $e / L$, compared to those of overstrength factors. Moreover, the differences between the values of these parameters are reduced by decreasing the number of storeys. In the 2-storey structure, the mentioned difference is observed in most of the ratios excluding $e / L=0.05$. Therefore, the higher effect of 


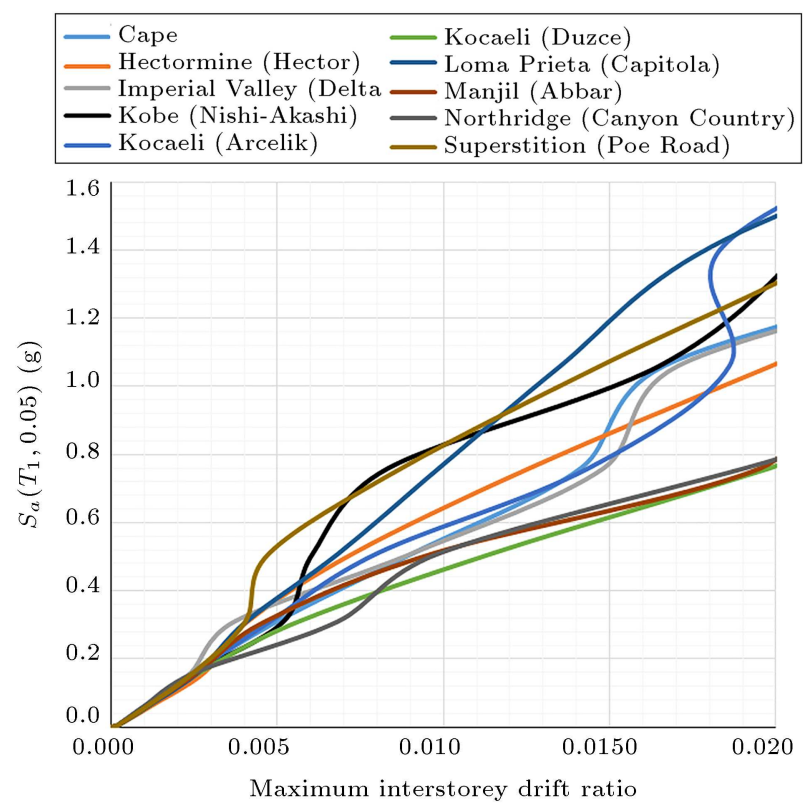

Figure 14. Incremental Dynamic Analysis (IDA) curves for 2-storey structure with $e / L=0.2$.

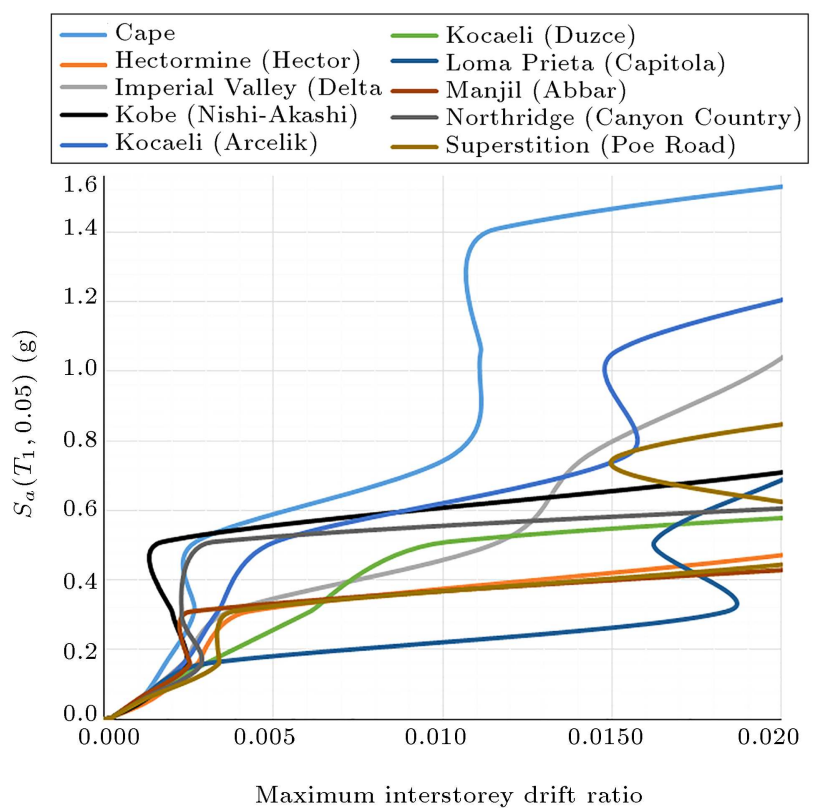

Figure 15. Incremental Dynamic Analysis (IDA curves for 6-storey structure with $e / L=0.05$.

ductility, compared to that of overstrength, is more significant in tall structures in comparison with short ones.

Regarding the response modification factor, the proper value of link beam length to span length ratio $(e / L)$ is 0.1 in 6 - and 10 -storey structures. However, this value $(e / L)$ is 0.05 in the 2 -storey structure due to the high value of the overstrength factor in this ratio, which results in a higher response modification factor. Therefore, better seismic behaviour for this kind of

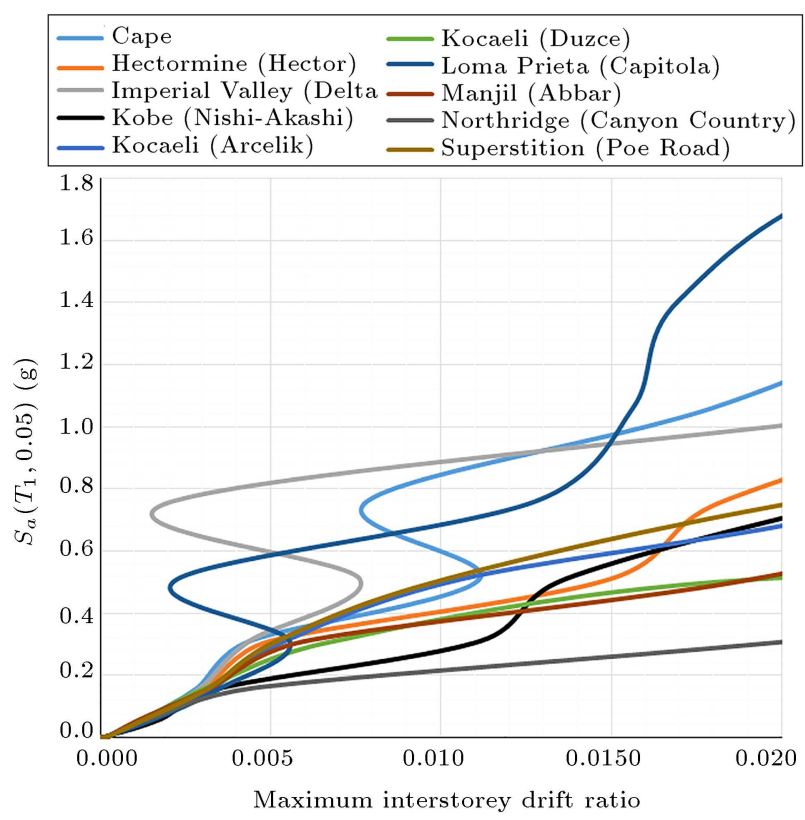

Figure 16. Incremental Dynamic Analysis (IDA) curves for 6-storey structure with $e / L=0.1$.

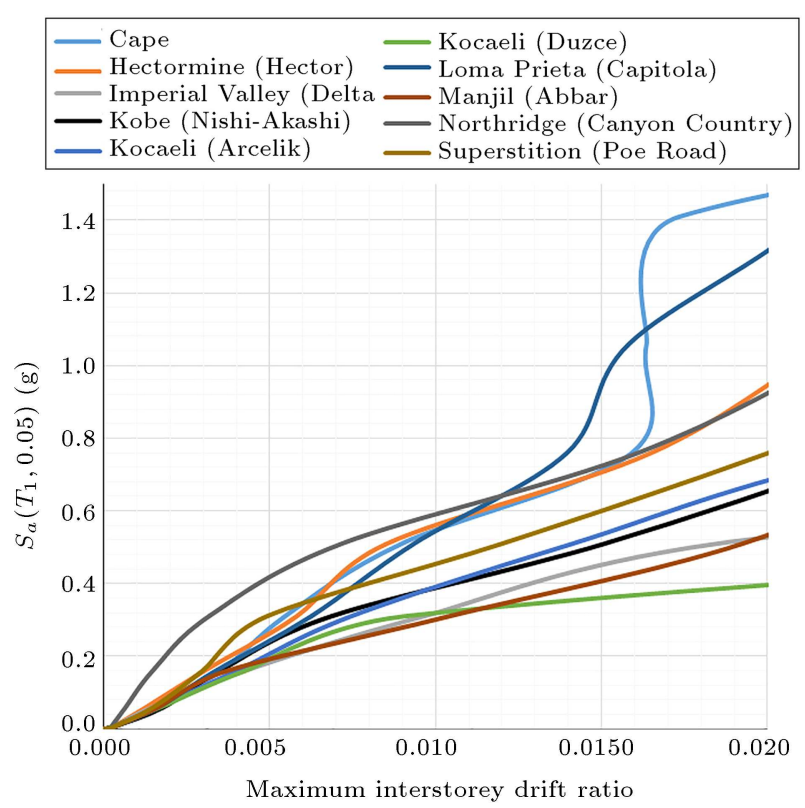

Figure 17. Incremental Dynamic Analysis (IDA) curves for 6 -storey structure with $e / L=0.15$.

bracing is achieved using $e / L$ of 0.05 in small structures and $e / L$ of 0.1 in tall structures.

\section{Fragility curves}

In order to better investigate the behaviour of the considered braces, the fragility curves are plotted according to $\log$ normal distribution, evaluating the damage probability of structures under different acceleration spectra. The fragility curves are mostly modeled 


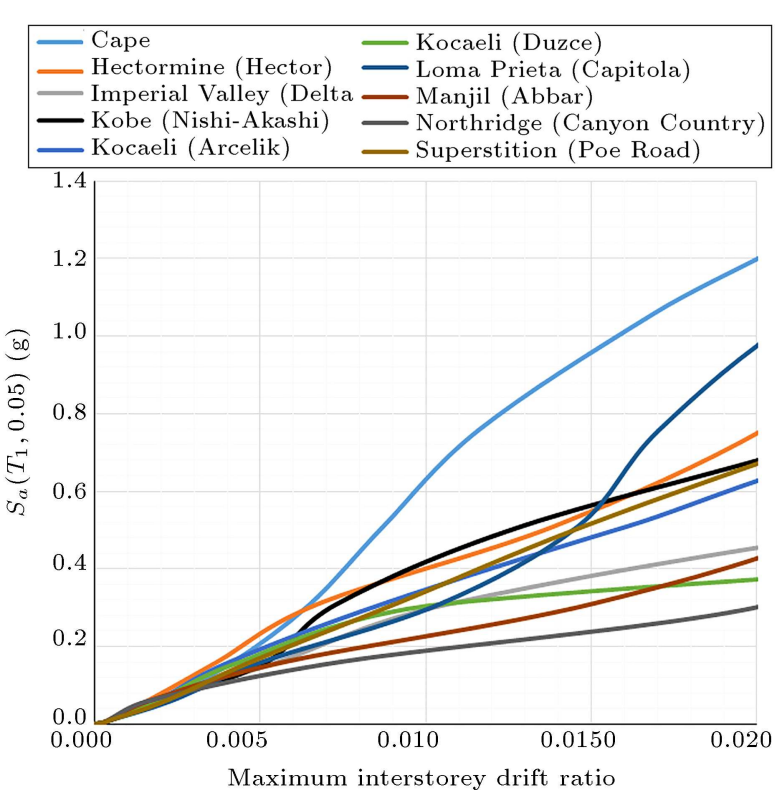

Figure 18. Incremental Dynamic Analysis (IDA) curves for 6 -storey structure with $e / L=0.2$.

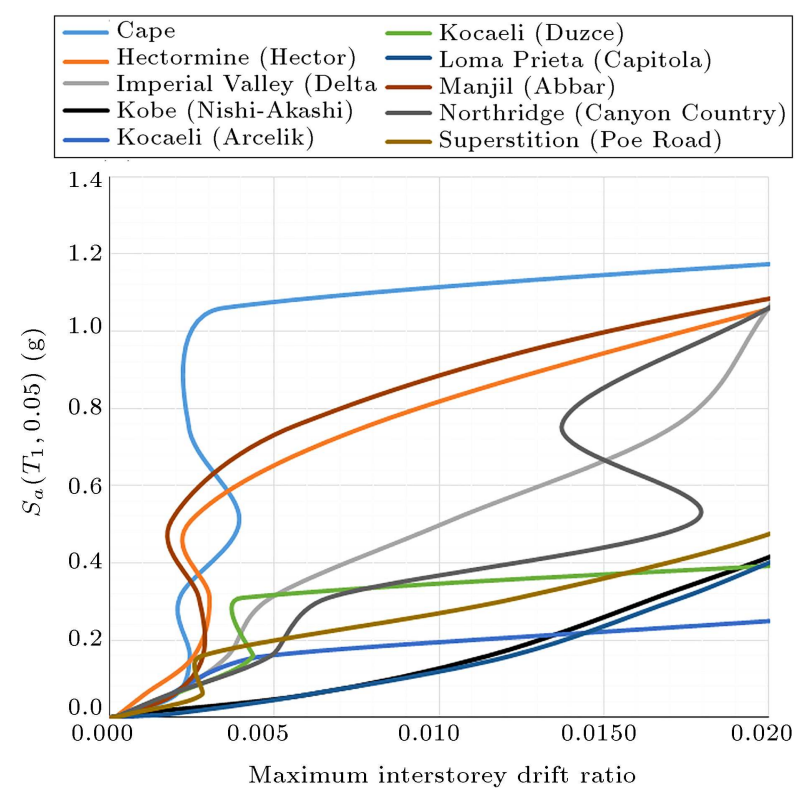

Figure 19. Incremental Dynamic Analysis (IDA) curves for 10-storey structure with $e / L=0.05$.

by cumulative log normal functions, presenting the occurrence probability or exceeding a damage status for a certain intensity scale of an earthquake [37-39]. In this research, the fragility curves are plotted according to the spectral acceleration in the period of structures, modeled in the form of a two parameters lognormal function. The occurrence probability of damage status $\left(D_{S i}\right)$ is obtained in a certain spectral acceleration, $S_{a}\left(T_{1}, g\right)$, as Eq. (7) [40]:

$$
P\left(D S \geq D_{s i} \mid S_{a}\left(T_{1}\right)\right)=\phi\left(\frac{\ln x-\lambda}{\beta}\right),
$$

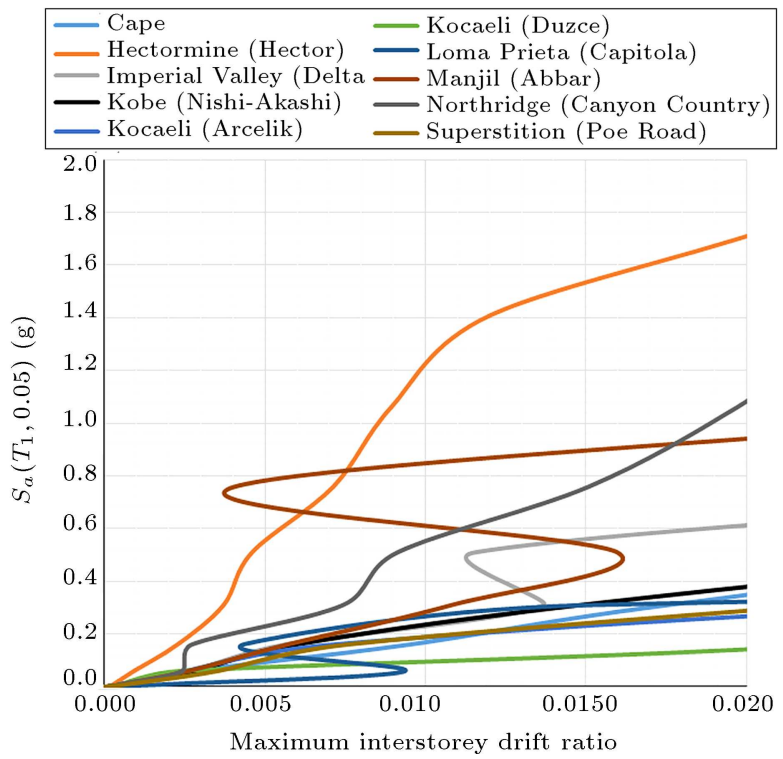

Figure 20. Incremental Dynamic Analysis (IDA) curves for 10-storey structure with $e / L=0.1$.

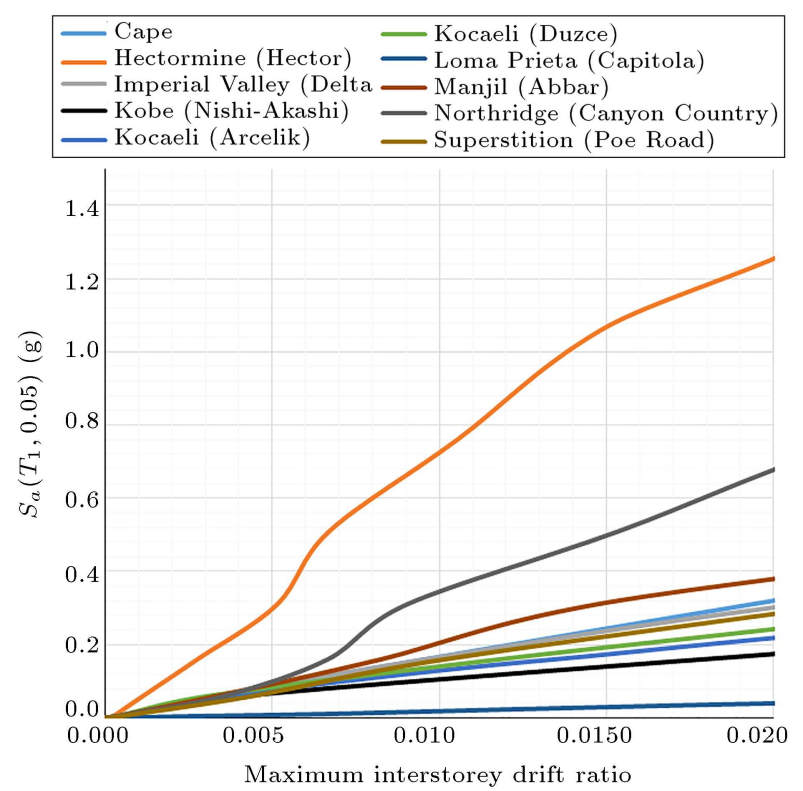

Figure 21. Incremental Dynamic Analysis (IDA) curves for 10-storey structure with $e / L=0.15$.

where, $\phi$ is the standard accumulative lognormal distribution function; $x$ is the spectral acceleration with lognormal distribution; and $\lambda$ and $\beta$ are average and standard deviation of $\ln x$. Damage criterion has been considered for the structures, presented in Table C1-3, based on the drift values and according to ASCE (4106) [41] guidelines, as $2 \%$ for Collapse Prevention (CP) and $0.5 \%$ for Immediate Occupancy (IO). Figures 2628 present the fragility curves for each structure for performance levels of IO and CP in different ratios of link beam length to span length.

Considering the fragility curves in the perfor- 
Table 6. The values of overstrength, ductility and response modification factors for 2-storey frame with $e / L=0.05$.

\begin{tabular}{|c|c|c|c|c|c|c|c|c|}
\hline Record & $\begin{array}{c}\text { Recording } \\
\text { station }\end{array}$ & $\begin{array}{c}V_{b(\text { Dyn }, u)} \\
\quad(\text { ton })\end{array}$ & $\begin{array}{c}V_{b(s t, y)} \\
(\text { ton })\end{array}$ & $\begin{array}{c}V_{b(D y n, e l)} \\
\quad(\text { ton })\end{array}$ & $\boldsymbol{R}_{\mu}$ & $\boldsymbol{R}_{s}$ & $\boldsymbol{R}_{\mathrm{LRFD}}$ & $\boldsymbol{R}_{\mathrm{ASD}}$ \\
\hline Cape Mendocino & Rio Dell Overpass & 119.54 & 27.73 & 250.06 & 2.09 & 4.31 & 9.02 & 12.62 \\
\hline Hector mine & Hector & 115.99 & 27.73 & 277.86 & 2.40 & 4.18 & 10.02 & 14.03 \\
\hline Imperial valley & Delta & 118.63 & 27.73 & 265.72 & 2.24 & 4.28 & 9.58 & 13.42 \\
\hline Kobe & Nishi-Akashi & 120.15 & 27.73 & 467.92 & 3.89 & 4.33 & 16.87 & 23.62 \\
\hline Kocaeli & Arcelik & 91.87 & 27.73 & 195.73 & 2.13 & 3.31 & 7.06 & 9.88 \\
\hline Kocaeli & Duzce & 100.95 & 27.73 & 277.05 & 2.74 & 3.64 & 9.99 & 13.99 \\
\hline Loma Prieta & Capitola & 118.84 & 27.73 & 473.32 & 3.98 & 4.29 & 17.07 & 23.90 \\
\hline Manjil & Abbar & 115.35 & 27.73 & 194.79 & 1.69 & 4.16 & 7.02 & 9.83 \\
\hline Northridge & Canyon Country & 108.60 & 27.73 & 310.00 & 2.85 & 3.92 & 11.18 & 15.65 \\
\hline Superstition & Poe Road & 98.33 & 27.73 & 270.38 & 2.75 & 3.55 & 9.75 & 13.65 \\
\hline Average & & & & & 2.68 & 4.00 & 10.76 & 15.06 \\
\hline$\sigma$ & & & & & 1.03 & 1.16 & 3.51 & 4.92 \\
\hline C.V. & & & & & 0.39 & 0.29 & 0.33 & 0.33 \\
\hline
\end{tabular}

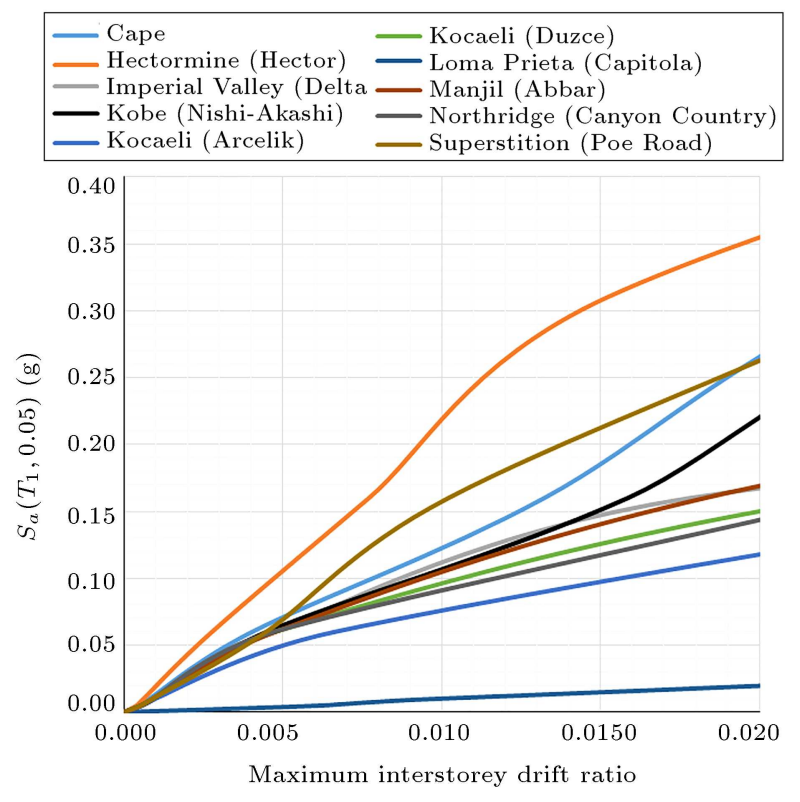

Figure 22. Incremental Dynamic Analysis (IDA) curves for 10-storey structure with $e / L=0.2$.

mance level of IO, the values of spectral acceleration are reduced by increasing the height of structures. Moreover, by increasing the $e / L$ ratio in a structure with constant storeys, lower spectral acceleration causes its damage curves at the performance level of IO.

The extension is observed in all fragility curves plotted for the performance level of $\mathrm{CP}$, indicating the effects of the contents of applied earthquakes for creating the considered damage. This extension is lower for the performance level of IO. Regarding the fragility curves, a 2-storey structure with $e / L=0.05$ presents the best seismic behaviour in the models with different $e / L$ ratios. However, $e / L=0.1$ is the appropriate ratio in the 6 - and 10 -storey structures.

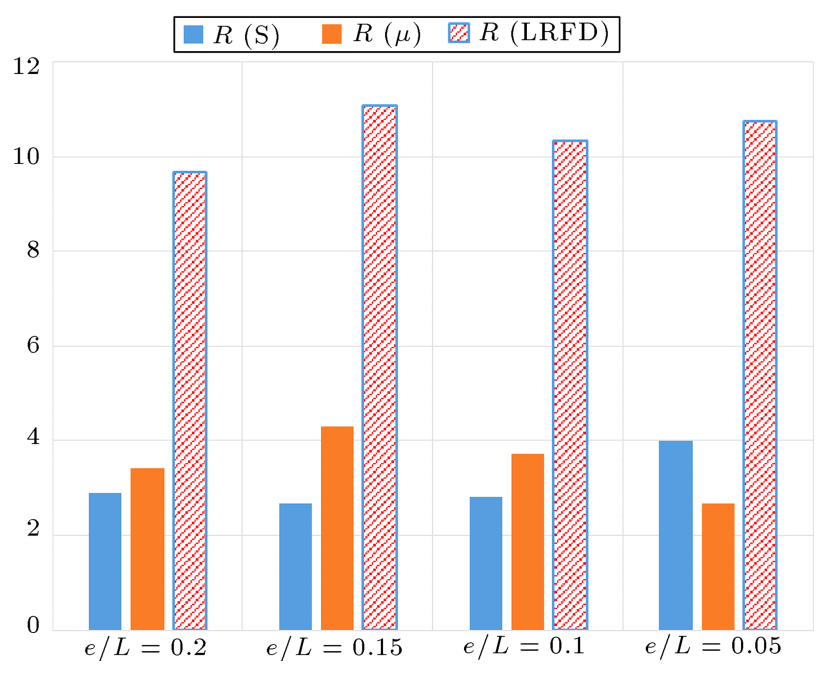

Figure 23. Ductility, overstrength and response modification factors of 2-storey structure.

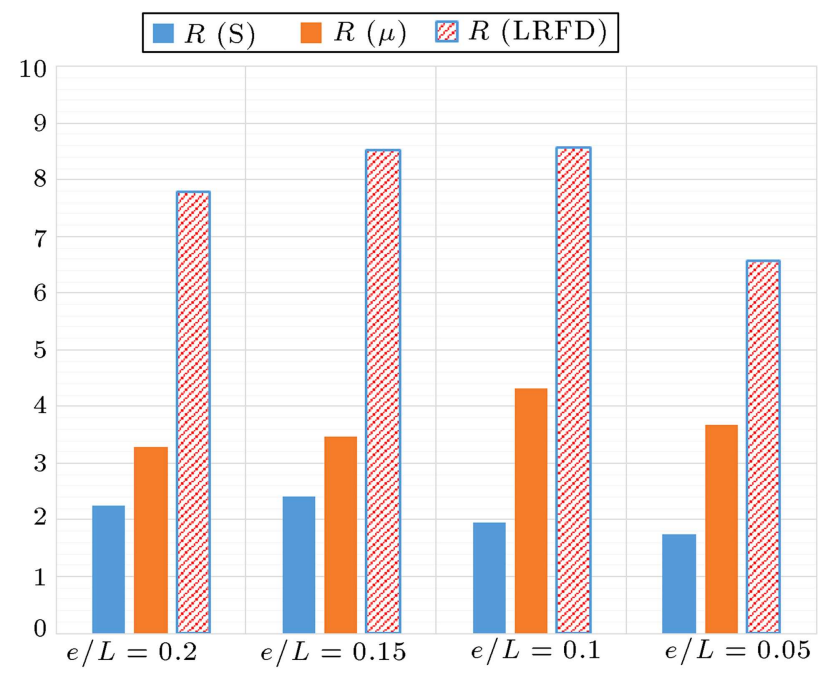

Figure 24. Ductility, overstrength and response modification factors of 6 -storey structure. 
Table 7. The values of overstrength, ductility and response modification factors for 2-storey frame with $e / L=0.1$.

\begin{tabular}{ccccccccc}
\hline Record & $\begin{array}{c}\text { Recording } \\
\text { station }\end{array}$ & $\begin{array}{c}\boldsymbol{V}_{\boldsymbol{b}(\boldsymbol{D} \boldsymbol{y} \boldsymbol{n}, \boldsymbol{u})} \\
(\text { ton })\end{array}$ & $\begin{array}{c}\boldsymbol{V}_{\boldsymbol{b}(\boldsymbol{s t}, \boldsymbol{y})} \\
(\text { ton })\end{array}$ & $\begin{array}{c}\boldsymbol{V}_{\boldsymbol{b}(\boldsymbol{D} \boldsymbol{y} \boldsymbol{n}, \boldsymbol{e l})} \\
(\mathbf{t o n})\end{array}$ & $\boldsymbol{R}_{\boldsymbol{\mu}}$ & $\boldsymbol{R}_{\boldsymbol{s}}$ & $\boldsymbol{R}_{\mathbf{L R F D}}$ & $\boldsymbol{R}_{\text {ASD }}$ \\
\hline Cape Mendocino & Rio Dell Overpass & 49.20 & 22.84 & 152.87 & 3.11 & 2.15 & 6.69 & 9.37 \\
Hector mine & Hector & 62.52 & 22.84 & 181.24 & 2.90 & 2.74 & 7.94 & 11.11 \\
Imperial valley & Delta & 44.45 & 22.84 & 180.82 & 4.07 & 1.95 & 7.92 & 11.08 \\
Kobe & Nishi-Akashi & 78.53 & 22.84 & 433.52 & 5.52 & 3.44 & 18.98 & 26.57 \\
Kocaeli & Arcelik & 72.22 & 22.84 & 190.94 & 2.64 & 3.16 & 8.36 & 11.70 \\
Kocaeli & Duzce & 61.03 & 22.84 & 211.62 & 3.47 & 2.67 & 9.27 & 12.97 \\
Loma Prieta & Capitola & 113.77 & 22.84 & 343.36 & 3.02 & 4.98 & 15.03 & 21.05 \\
Manjil & Abbar & 52.03 & 22.84 & 143.92 & 2.77 & 2.28 & 6.30 & 8.82 \\
Northridge & Canyon Country & 55.94 & 22.84 & 219.73 & 3.93 & 2.45 & 9.62 & 13.47 \\
Superstition & Poe Road & 53.81 & 22.84 & 305.84 & 5.68 & 2.36 & 13.39 & 18.75 \\
Average & & & & & 3.71 & 2.82 & 10.35 & 14.49 \\
$\sigma$ & & & & & 1.08 & 0.84 & 3.97 & 5.55 \\
C.V. & & & & & 0.29 & 0.30 & 0.38 & 0.38 \\
\hline
\end{tabular}

Table 8. The values of overstrength, ductility and response modification factors for 2-storey frame with $e / L=0.15$.

\begin{tabular}{ccccccccc}
\hline Record & $\begin{array}{c}\text { Recording } \\
\text { station }\end{array}$ & $\begin{array}{c}\boldsymbol{V}_{b(\text { Dyn }, u)} \\
(\text { ton })\end{array}$ & $\begin{array}{c}\boldsymbol{V}_{b(s t, y)} \\
(\text { ton })\end{array}$ & $\begin{array}{c}\boldsymbol{V}_{b(\text { Dyn,el })} \\
(\text { ton })\end{array}$ & $\boldsymbol{R}_{\boldsymbol{\mu}}$ & $\boldsymbol{R}_{\boldsymbol{s}}$ & $\boldsymbol{R}_{\mathbf{L R F D}}$ & $\boldsymbol{R}_{\text {ASD }}$ \\
\hline Cape Mendocino & Rio Dell Overpass & 55.02 & 22.34 & 143.07 & 2.60 & 2.46 & 6.40 & 8.97 \\
Hector mine & Hector & 57.74 & 22.34 & 326.27 & 5.65 & 2.58 & 14.60 & 20.45 \\
Imperial valley & Delta & 40.07 & 22.34 & 155.09 & 3.87 & 1.79 & 6.94 & 9.72 \\
Kobe & Nishi-Akashi & 62.85 & 22.34 & 429.24 & 6.83 & 2.81 & 19.21 & 26.90 \\
Kocaeli & Arcelik & 72.93 & 22.34 & 243.29 & 3.34 & 3.26 & 10.89 & 15.25 \\
Kocaeli & Duzce & 53.83 & 22.34 & 110.58 & 2.05 & 2.41 & 4.95 & 6.93 \\
Loma Prieta & Capitola & 111.66 & 22.34 & 279.19 & 2.50 & 5.00 & 12.50 & 17.50 \\
Manjil & Abbar & 46.73 & 22.34 & 157.27 & 3.37 & 2.09 & 7.04 & 9.86 \\
Northridge & Canyon Country & 50.67 & 22.34 & 213.21 & 4.21 & 2.27 & 9.54 & 13.36 \\
Superstition & Poe Road & 48.89 & 22.34 & 417.12 & 8.53 & 2.19 & 18.67 & 26.14 \\
Average & & & & & 4.29 & 2.69 & 11.08 & 15.51 \\
$\sigma$ & & & & & 2.17 & 0.88 & 5.03 & 7.04 \\
C.V. & & & & & 0.50 & 0.33 & 0.45 & 0.45 \\
\hline
\end{tabular}

Table 9. The values of overstrength, ductility and response modification factors for 2 -storey frame with $e / L=0.2$.

\begin{tabular}{|c|c|c|c|c|c|c|c|c|}
\hline Record & $\begin{array}{c}\text { Recording } \\
\text { station }\end{array}$ & $\begin{array}{c}V_{b(D y n, u)} \\
(\text { ton })\end{array}$ & $\begin{array}{c}V_{b(s t, y)} \\
(\text { ton })\end{array}$ & $\begin{array}{c}V_{b(D y n, e l)} \\
(\text { ton })\end{array}$ & $\boldsymbol{R}_{\mu}$ & $\boldsymbol{R}_{s}$ & $\boldsymbol{R}_{\mathrm{LRFD}}$ & $\boldsymbol{R}_{\mathrm{ASD}}$ \\
\hline Cape Mendocino & Rio Dell Overpass & 70.31 & 21.67 & 160.72 & 2.29 & 3.24 & 7.42 & 10.38 \\
\hline Hector mine & Hector & 64.68 & 21.67 & 223.94 & 3.46 & 2.98 & 10.33 & 14.47 \\
\hline Imperial valley & Delta & 49.64 & 21.67 & 233.83 & 4.71 & 2.29 & 10.79 & 15.11 \\
\hline Kobe & Nishi-Akashi & 69.34 & 21.67 & 378.00 & 5.45 & 3.20 & 17.44 & 24.42 \\
\hline Kocaeli & Arcelik & 68.35 & 21.67 & 244.06 & 3.57 & 3.15 & 11.26 & 15.77 \\
\hline Kocaeli & Duzce & 50.85 & 21.67 & 93.73 & 1.84 & 2.35 & 4.33 & 6.06 \\
\hline Loma Prieta & Capitola & 101.50 & 21.67 & 225.49 & 2.22 & 4.68 & 10.41 & 14.57 \\
\hline Manjil & Abbar & 50.21 & 21.67 & 125.08 & 2.49 & 2.32 & 5.77 & 8.08 \\
\hline Northridge & Canyon Country & 51.51 & 21.67 & 170.92 & 3.32 & 2.38 & 7.89 & 11.04 \\
\hline Superstition & Poe Road & 49.41 & 21.67 & 241.24 & 4.88 & 2.28 & 11.13 & 15.59 \\
\hline Average & & & & & 3.42 & 2.89 & 9.68 & 13.55 \\
\hline$\sigma$ & & & & & 1.18 & 0.72 & 3.45 & 4.84 \\
\hline C.V. & & & & & 0.35 & 0.25 & 0.36 & 0.36 \\
\hline
\end{tabular}


Table 10. The values of overstrength, ductility and response modification factors for 6 -storey frame with $e / L=0.05$.

\begin{tabular}{|c|c|c|c|c|c|c|c|c|}
\hline Record & $\begin{array}{c}\text { Recording } \\
\text { station }\end{array}$ & $\begin{array}{c}V_{b(\text { Dyn }, u)} \\
\quad(\text { ton })\end{array}$ & $\begin{array}{c}V_{b(s t, y)} \\
(\text { ton })\end{array}$ & $\begin{array}{c}V_{b(D y n, e l)} \\
\quad(\text { ton })\end{array}$ & $\boldsymbol{R}_{\mu}$ & $\boldsymbol{R}_{s}$ & $\boldsymbol{R}_{\mathrm{LRFD}}$ & $\boldsymbol{R}_{\mathrm{ASD}}$ \\
\hline Cape Mendocino & Rio Dell Overpass & 86.95 & 46.50 & 521.12 & 5.99 & 1.87 & 11.21 & 15.69 \\
\hline Hector mine & Hector & 85.36 & 46.50 & 108.06 & 1.27 & 1.84 & 2.32 & 3.25 \\
\hline Imperial valley & Delta & 77.40 & 46.50 & 326.99 & 4.22 & 1.66 & 7.03 & 9.84 \\
\hline Kobe & Nishi-Akashi & 112.04 & 46.50 & 355.89 & 3.18 & 2.41 & 7.65 & 10.71 \\
\hline Kocaeli & Arcelik & 94.40 & 46.50 & 569.02 & 6.03 & 2.03 & 12.24 & 17.13 \\
\hline Kocaeli & Duzce & 68.08 & 46.50 & 270.22 & 3.97 & 1.46 & 5.81 & 8.14 \\
\hline Loma Prieta & Capitola & 85.04 & 46.50 & 435.57 & 5.12 & 1.83 & 9.37 & 13.11 \\
\hline Manjil & Abbar & 46.80 & 46.50 & 136.87 & 2.92 & 1.01 & 2.94 & 4.12 \\
\hline Northridge & Canyon Country & 66.69 & 46.50 & 104.50 & 1.57 & 1.43 & 2.25 & 3.15 \\
\hline Superstition & Poe Road & 89.40 & 46.50 & 229.41 & 2.57 & 1.92 & 4.93 & 6.91 \\
\hline Average & & & & & 3.68 & 1.75 & 6.58 & 9.21 \\
\hline$\sigma$ & & & & & 1.65 & 0.62 & 3.61 & 5.06 \\
\hline C.V. & & & & & 0.45 & 0.36 & 0.55 & 0.55 \\
\hline
\end{tabular}

Table 11. The values of overstrength, ductility and response modification factors for 6-storey frame with $e / L=0.1$.

\begin{tabular}{ccccccccc}
\hline Record & $\begin{array}{c}\text { Recording } \\
\text { station }\end{array}$ & $\begin{array}{c}\boldsymbol{V}_{b(\text { Dyn,u) }} \\
(\text { ton })\end{array}$ & $\begin{array}{c}\boldsymbol{V}_{b(s t, y)} \\
(\text { ton })\end{array}$ & $\begin{array}{c}\boldsymbol{V}_{b(\text { Dyn,el })} \\
(\text { ton })\end{array}$ & $\boldsymbol{R}_{\boldsymbol{\mu}}$ & $\boldsymbol{R}_{\boldsymbol{s}}$ & $\boldsymbol{R}_{\text {LRFD }}$ & $\boldsymbol{R}_{\text {ASD }}$ \\
\hline Cape Mendocino & Rio Dell Overpass & 75.78 & 45.84 & 391.52 & 5.17 & 1.65 & 8.54 & 11.96 \\
Hector mine & Hector & 88.08 & 45.84 & 438.31 & 4.98 & 1.92 & 9.56 & 13.39 \\
Imperial valley & Delta & 80.84 & 45.84 & 527.96 & 6.53 & 1.76 & 11.52 & 16.12 \\
Kobe & Nishi-Akashi & 100.25 & 45.84 & 482.97 & 4.82 & 2.19 & 10.54 & 14.75 \\
Kocaeli & Arcelik & 86.16 & 45.84 & 416.39 & 4.83 & 1.88 & 9.08 & 12.72 \\
Kocaeli & Duzce & 77.03 & 45.84 & 270.81 & 3.52 & 1.68 & 5.91 & 8.27 \\
Loma Prieta & Capitola & 129.51 & 45.84 & 708.65 & 5.47 & 2.83 & 15.46 & 21.64 \\
Manjil & Abbar & 82.55 & 45.84 & 222.90 & 2.70 & 1.80 & 4.86 & 6.81 \\
Northridge & Canyon Country & 84.94 & 45.84 & 156.38 & 1.84 & 1.85 & 3.41 & 4.78 \\
Superstition & Poe Road & 92.05 & 45.84 & 317.69 & 3.45 & 2.01 & 6.93 & 9.70 \\
Average & & & & & 4.33 & 1.96 & 8.58 & 12.01 \\
$\sigma$ & & & & & 1.69 & 0.44 & 3.43 & 4.81 \\
C.V. & & & & & 0.39 & 0.22 & 0.40 & 0.40 \\
\hline
\end{tabular}

Table 12. The values of overstrength, ductility and response modification factors for 6 -storey frame with $e / L=0.15$.

\begin{tabular}{ccccccccc}
\hline Record & $\begin{array}{c}\text { Recording } \\
\text { station }\end{array}$ & $\begin{array}{c}\boldsymbol{V}_{\boldsymbol{b}(\boldsymbol{D} \boldsymbol{y}, \boldsymbol{u})} \\
(\text { ton })\end{array}$ & $\begin{array}{c}\boldsymbol{V}_{\boldsymbol{b}(\boldsymbol{s t}, \boldsymbol{y})} \\
(\text { ton })\end{array}$ & $\begin{array}{c}\boldsymbol{V}_{\boldsymbol{b}(\boldsymbol{D} \boldsymbol{y}, \boldsymbol{e l})} \\
(\text { ton })\end{array}$ & $\boldsymbol{R}_{\boldsymbol{\mu}}$ & $\boldsymbol{R}_{\boldsymbol{s}}$ & $\boldsymbol{R}_{\mathbf{L R F D}}$ & $\boldsymbol{R}_{\text {ASD }}$ \\
\hline Cape Mendocino & Rio Dell Overpass & 114.02 & 44.71 & 592.74 & 5.20 & 2.55 & 13.26 & 18.56 \\
Hector mine & Hector & 117.84 & 44.71 & 453.17 & 3.85 & 2.64 & 10.14 & 14.19 \\
Imperial valley & Delta & 96.27 & 44.71 & 433.05 & 4.50 & 2.15 & 9.69 & 13.56 \\
Kobe & Nishi-Akashi & 119.76 & 44.71 & 444.82 & 3.71 & 2.68 & 9.95 & 13.93 \\
Kocaeli & Arcelik & 86.72 & 44.71 & 301.14 & 3.47 & 1.94 & 6.74 & 9.43 \\
Kocaeli & Duzce & 85.82 & 44.71 & 224.77 & 2.62 & 1.92 & 5.03 & 7.04 \\
Loma Prieta & Capitola & 129.77 & 44.71 & 672.29 & 5.18 & 2.90 & 15.04 & 21.05 \\
Manjil & Abbar & 107.58 & 44.71 & 230.91 & 2.15 & 2.41 & 5.16 & 7.23 \\
Northridge & Canyon Country & 114.45 & 44.71 & 158.81 & 1.39 & 2.56 & 3.55 & 4.97 \\
Superstition & Poe Road & 108.78 & 44.71 & 296.93 & 2.73 & 2.43 & 6.64 & 9.30 \\
Average & & & & & 3.48 & 2.42 & 8.52 & 11.93 \\
$\sigma$ & & & & & 1.22 & 0.35 & 3.62 & 5.07 \\
C.V. & & & & & 0.35 & 0.14 & 0.43 & 0.43 \\
\hline
\end{tabular}


Table 13. The values of overstrength, ductility and response modification factors for 6-storey frame with $e / L=0.2$.

\begin{tabular}{|c|c|c|c|c|c|c|c|c|}
\hline Record & $\begin{array}{c}\text { Recording } \\
\text { station }\end{array}$ & $\begin{array}{c}V_{b(D y n, u)} \\
\quad(\text { ton })\end{array}$ & $\begin{array}{c}V_{b(s t, y)} \\
(\text { ton })\end{array}$ & $\begin{array}{c}V_{b(D y n, e l)} \\
\quad(\text { ton })\end{array}$ & $\boldsymbol{R}_{\mu}$ & $\boldsymbol{R}_{s}$ & $\boldsymbol{R}_{\text {LRFD }}$ & $\boldsymbol{R}_{\mathrm{ASD}}$ \\
\hline Cape Mendocino & Rio Dell Overpass & 108.23 & 41.84 & 486.79 & 4.50 & 2.59 & 11.63 & 16.29 \\
\hline Hector mine & Hector & 96.48 & 41.84 & 325.58 & 3.37 & 2.31 & 7.78 & 10.89 \\
\hline Imperial valley & Delta & 86.51 & 41.84 & 235.77 & 2.73 & 2.07 & 5.64 & 7.89 \\
\hline Kobe & Nishi-Akashi & 98.74 & 41.84 & 349.23 & 3.54 & 2.36 & 8.35 & 11.69 \\
\hline Kocaeli & Arcelik & 81.77 & 41.84 & 296.48 & 3.63 & 1.95 & 7.09 & 9.92 \\
\hline Kocaeli & Duzce & 74.73 & 41.84 & 164.30 & 2.20 & 1.79 & 3.93 & 5.50 \\
\hline Loma Prieta & Capitola & 127.18 & 41.84 & 752.77 & 5.92 & 3.04 & 17.99 & 25.19 \\
\hline Manjil & Abbar & 92.50 & 41.84 & 216.75 & 2.34 & 2.21 & 5.18 & 7.25 \\
\hline Northridge & Canyon Country & 80.84 & 41.84 & 148.46 & 1.84 & 1.93 & 3.55 & 4.97 \\
\hline Superstition & Poe Road & 95.58 & 41.84 & 277.94 & 2.91 & 2.28 & 6.64 & 9.30 \\
\hline Average & & & & & 3.30 & 2.25 & 7.78 & 10.89 \\
\hline$\sigma$ & & & & & 1.15 & 0.35 & 4.07 & 5.69 \\
\hline C.V. & & & & & 0.35 & 0.15 & 0.52 & 0.52 \\
\hline
\end{tabular}

Table 14. The values of overstrength, ductility and response modification factors for 10-storey frame with $e / L=0.2$.

\begin{tabular}{ccccccccc}
\hline Record & $\begin{array}{c}\text { Recording } \\
\text { station }\end{array}$ & $\begin{array}{c}\boldsymbol{V}_{\boldsymbol{b}(\boldsymbol{D} \boldsymbol{y}, \boldsymbol{u})} \\
\text { (ton) }\end{array}$ & $\begin{array}{c}\boldsymbol{V}_{\boldsymbol{b}(\boldsymbol{s t}, \boldsymbol{y})} \\
(\text { ton })\end{array}$ & $\begin{array}{c}\boldsymbol{V}_{\boldsymbol{b}(\boldsymbol{D} \boldsymbol{y} \boldsymbol{n}, \boldsymbol{e l})} \\
(\text { ton })\end{array}$ & $\boldsymbol{R}_{\boldsymbol{\mu}}$ & $\boldsymbol{R}_{\boldsymbol{s}}$ & $\boldsymbol{R}_{\mathbf{L R F D}}$ & $\boldsymbol{R}_{\text {ASD }}$ \\
\hline Cape Mendocino & Rio Dell Overpass & 81.69 & 52.88 & 81.69 & 1.00 & 1.54 & 1.54 & 2.16 \\
Hector mine & Hector & 112.09 & 52.88 & 653.82 & 5.83 & 2.12 & 12.36 & 17.31 \\
Imperial valley & Delta & 120.42 & 52.88 & 526.43 & 4.37 & 2.28 & 9.96 & 13.94 \\
Kobe & Nishi-Akashi & 120.91 & 52.88 & 120.91 & 1.00 & 2.29 & 2.29 & 3.20 \\
Kocaeli & Arcelik & 82.95 & 52.88 & 211.76 & 2.55 & 1.57 & 4.00 & 5.61 \\
Kocaeli & Duzce & 106.65 & 52.88 & 238.92 & 2.24 & 2.02 & 4.52 & 6.33 \\
Loma Prieta & Capitola & 60.75 & 52.88 & 755.08 & 12.43 & 1.15 & 14.28 & 19.99 \\
Manjil & Abbar & 64.60 & 52.88 & 150.37 & 2.33 & 1.22 & 2.84 & 3.98 \\
Northridge & Canon Country & 80.03 & 52.88 & 385.03 & 4.81 & 1.51 & 7.28 & 10.19 \\
Superstition & Poe Road & 111.58 & 52.88 & 411.13 & 3.68 & 2.11 & 7.77 & 10.88 \\
Average & & & & & 4.02 & 1.78 & 6.69 & 9.36 \\
$\sigma$ & & & & & 3.60 & 0.53 & 5.35 & 7.49 \\
C.V. & & & & & 0.89 & 0.30 & 0.80 & 0.80 \\
\hline
\end{tabular}

Table 15. The values of overstrength, ductility and response modification factors for 10 -storey frame with $e / L=0.15$.

\begin{tabular}{|c|c|c|c|c|c|c|c|c|}
\hline Record & $\begin{array}{c}\text { Recording } \\
\text { station }\end{array}$ & $\begin{array}{c}V_{b(D y n, u)} \\
(\text { ton })\end{array}$ & $\begin{array}{c}V_{b(s t, y)} \\
(\text { ton })\end{array}$ & $\begin{array}{c}V_{b(D y n, e l)} \\
(\text { ton })\end{array}$ & $\boldsymbol{R}_{\mu}$ & $\boldsymbol{R}_{s}$ & $\boldsymbol{R}_{\text {LRFD }}$ & $\boldsymbol{R}_{\mathrm{ASD}}$ \\
\hline Cape Mendocino & Rio Dell Overpass & 108.76 & 50.46 & 317.49 & 2.92 & 2.16 & 6.29 & 8.81 \\
\hline Hector mine & Hector & 103.17 & 50.46 & 396.18 & 3.84 & 2.04 & 7.85 & 10.99 \\
\hline Imperial valley & Delta & 99.97 & 50.46 & 428.52 & 4.29 & 1.98 & 8.49 & 11.89 \\
\hline Kobe & Nishi-Akashi & 106.52 & 50.46 & 378.54 & 3.55 & 2.11 & 7.50 & 10.50 \\
\hline Kocaeli & Arcelik & 104.01 & 50.46 & 245.89 & 2.36 & 2.06 & 4.87 & 6.82 \\
\hline Kocaeli & Duzce & 54.51 & 50.46 & 127.90 & 2.35 & 1.08 & 2.53 & 3.55 \\
\hline Loma Prieta & Capitola & 102.25 & 50.46 & 987.16 & 9.65 & 2.03 & 19.56 & 27.39 \\
\hline Manjil & Abbar & 83.89 & 50.46 & 345.78 & 4.12 & 1.66 & 6.85 & 9.59 \\
\hline Northridge & Canyon Country & 83.71 & 50.46 & 615.02 & 7.35 & 1.66 & 12.19 & 17.06 \\
\hline Superstition & Poe Road & 107.63 & 50.46 & 268.02 & 2.49 & 2.13 & 5.31 & 7.44 \\
\hline Average & & & & & 4.29 & 1.89 & 8.15 & 11.40 \\
\hline$\sigma$ & & & & & 3.00 & 0.55 & 6.58 & 9.22 \\
\hline C.V. & & & & & 0.70 & 0.29 & 0.81 & 0.81 \\
\hline
\end{tabular}


Table 16. The values of overstrength, ductility and response modification factors for 10-storey frame with $e / L=0.1$.

\begin{tabular}{|c|c|c|c|c|c|c|c|c|}
\hline Record & $\begin{array}{c}\text { Recording } \\
\text { station }\end{array}$ & $\begin{array}{c}V_{b(D y n, u)} \\
\quad(\text { ton })\end{array}$ & $\begin{array}{c}V_{b(s t, y)} \\
(\text { ton) }\end{array}$ & $\begin{array}{c}V_{b(D y n, e l)} \\
\quad(\text { ton })\end{array}$ & $\boldsymbol{R}_{\mu}$ & $\boldsymbol{R}_{s}$ & $\boldsymbol{R}_{\text {LRFD }}$ & $\boldsymbol{R}_{\mathrm{ASD}}$ \\
\hline Cape Mendocino & Rio Dell Overpass & 77.82 & 49.03 & 186.75 & 2.40 & 1.59 & 3.81 & 5.33 \\
\hline Hector mine & Hector & 89.36 & 49.03 & 326.90 & 3.66 & 1.82 & 6.67 & 9.33 \\
\hline Imperial valley & Delta & 84.11 & 49.03 & 240.80 & 2.86 & 1.72 & 4.91 & 6.88 \\
\hline Kobe & Nishi-Akashi & 103.97 & 49.03 & 205.97 & 1.98 & 2.12 & 4.20 & 5.88 \\
\hline Kocaeli & Arcelik & 97.14 & 49.03 & 139.01 & 1.43 & 1.98 & 2.84 & 3.97 \\
\hline Kocaeli & Duzce & 86.62 & 49.03 & 149.26 & 1.72 & 1.77 & 3.04 & 4.26 \\
\hline Loma Prieta & Capitola & 98.85 & 49.03 & 333.01 & 3.37 & 2.02 & 6.79 & 9.51 \\
\hline Manjil & Abbar & 79.01 & 49.03 & 215.04 & 2.72 & 1.61 & 4.39 & 6.14 \\
\hline Northridge & Canyon Country & 66.36 & 49.03 & 541.49 & 8.16 & 1.35 & 11.04 & 15.46 \\
\hline Superstition & Poe Road & 98.20 & 49.03 & 239.96 & 2.44 & 2.00 & 4.89 & 6.85 \\
\hline Average & & & & & 3.08 & 1.80 & 5.26 & 7.36 \\
\hline$\sigma$ & & & & & 1.96 & 0.42 & 2.99 & 4.19 \\
\hline C.V. & & & & & 0.64 & 0.24 & 0.57 & 0.57 \\
\hline
\end{tabular}

Table 17. The values of overstrength, ductility and response modification factors for 10-storey frame with $e / L=0.05$.

\begin{tabular}{|c|c|c|c|c|c|c|c|c|}
\hline Record & $\begin{array}{c}\text { Recording } \\
\text { station }\end{array}$ & $\begin{array}{l}V_{b(D y n, u)} \\
\quad(\text { ton })\end{array}$ & $\begin{array}{c}V_{b(s t, y)} \\
(\text { ton) }\end{array}$ & $\begin{array}{l}V_{b(D y n, e l)} \\
\quad(\text { ton })\end{array}$ & $\boldsymbol{R}_{\mu}$ & $\boldsymbol{R}_{s}$ & $\boldsymbol{R}_{\mathrm{LRFD}}$ & $\boldsymbol{R}_{\mathrm{ASD}}$ \\
\hline Cape Mendocino & Rio Dell Overpass & 67.41 & 48.21 & 156.90 & 2.33 & 1.40 & 3.25 & 4.56 \\
\hline Hector mine & Hector & 70.66 & 48.21 & 161.49 & 2.29 & 1.47 & 3.35 & 4.69 \\
\hline Imperial valley & Delta & 62.93 & 48.21 & 138.01 & 2.19 & 1.31 & 2.86 & 4.01 \\
\hline Kobe & Nishi-Akashi & 90.80 & 48.21 & 209.89 & 2.31 & 1.88 & 4.35 & 6.10 \\
\hline Kocaeli & Arcelik & 75.86 & 48.21 & 131.11 & 1.73 & 1.57 & 2.72 & 3.81 \\
\hline Kocaeli & Duzce & 64.82 & 48.21 & 130.94 & 2.02 & 1.34 & 2.72 & 3.80 \\
\hline Loma Prieta & Capitola & 71.38 & 48.21 & 182.48 & 2.56 & 1.48 & 3.79 & 5.30 \\
\hline Manjil & Abbar & 61.34 & 48.21 & 134.06 & 2.19 & 1.27 & 2.78 & 3.89 \\
\hline Northridge & Canyon Country & 50.56 & 48.21 & 155.83 & 3.08 & 1.05 & 3.23 & 4.53 \\
\hline Superstition & Poe Road & 78.77 & 48.21 & 211.43 & 2.68 & 1.63 & 4.39 & 6.14 \\
\hline Average & & & & & 2.34 & 1.44 & 3.34 & 4.68 \\
\hline$\sigma$ & & & & & 0.35 & 0.22 & 0.60 & 0.85 \\
\hline C.V. & & & & & 0.15 & 0.15 & 0.18 & 0.18 \\
\hline
\end{tabular}

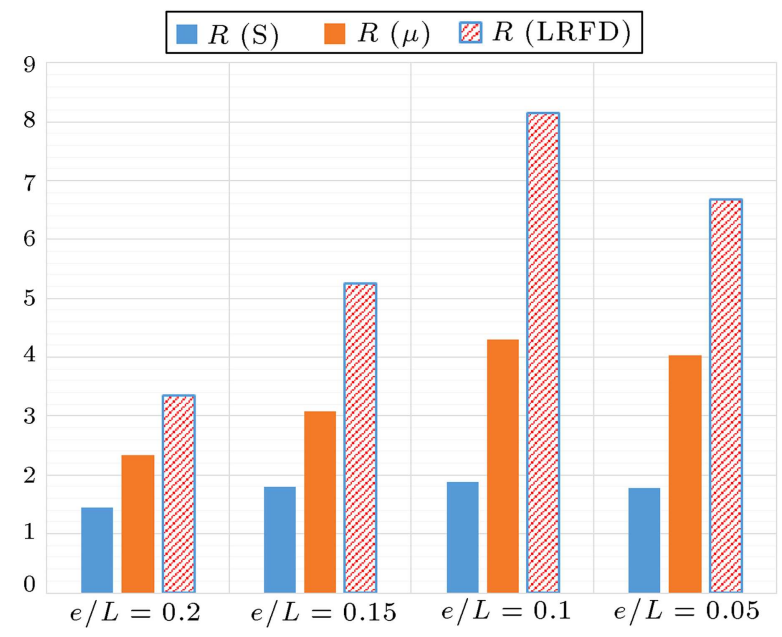

Figure 25. Ductility, overstrength and response modification factors of 10-storey structure.

\section{Discussion on the results}

As IDA is time and high energy consuming, it is not possible to consider as many models for investigating the effects of the ratio of link beam length to span length, as well as the height of a structure, on the seismic behaviour of eccentrically split-X braced frames.

In this research, 12 models are studied with different heights and link beam length to span length ratios. Based on the obtained results, the stiffness of structures is reduced by increasing the length of the link beam. The reason for this is that the angle between the bracing and horizontal direction increases in the structure with a longer link beam; and, therefore, the stiffness of bracing decreases against lateral loads. The structure presents more ductility with the increase of $e / L$ ratio values. As the fundamental period of 

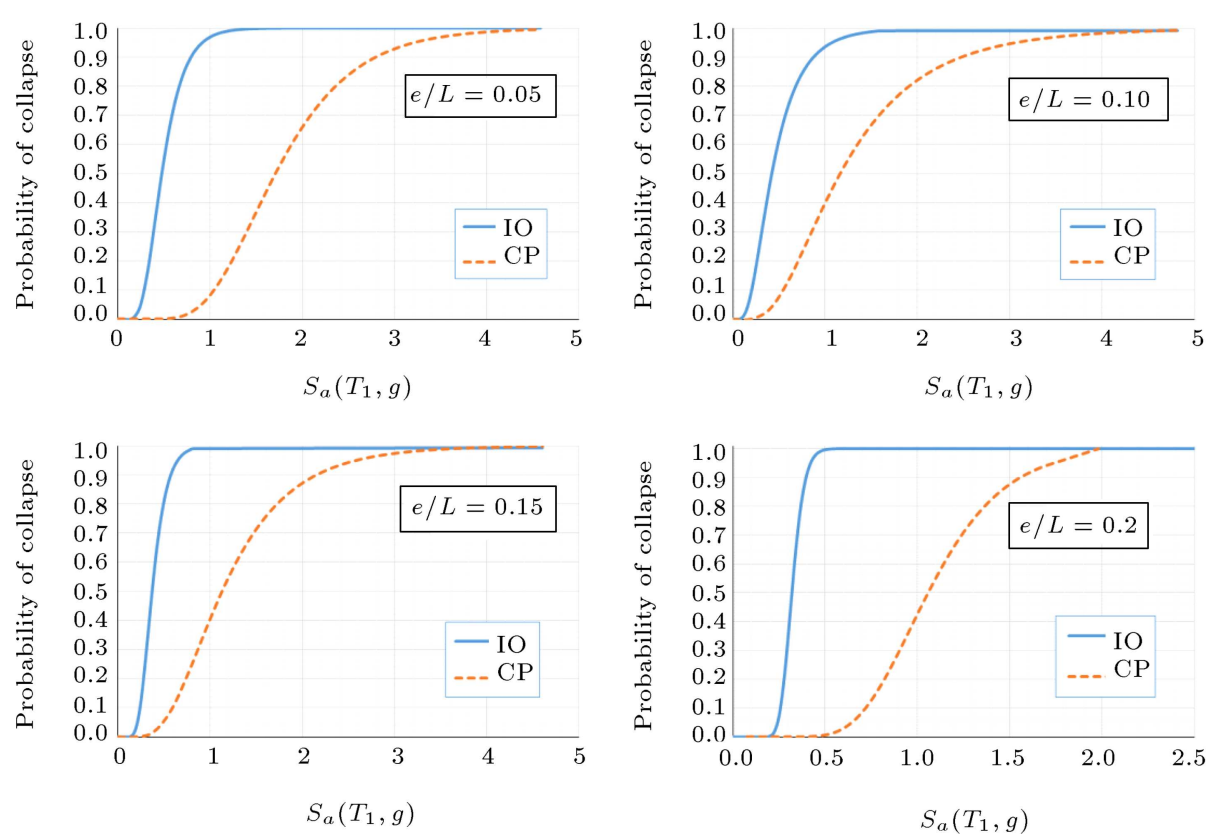

Figure 26. Fragility curves for 2-storey structure for different $e / L$.
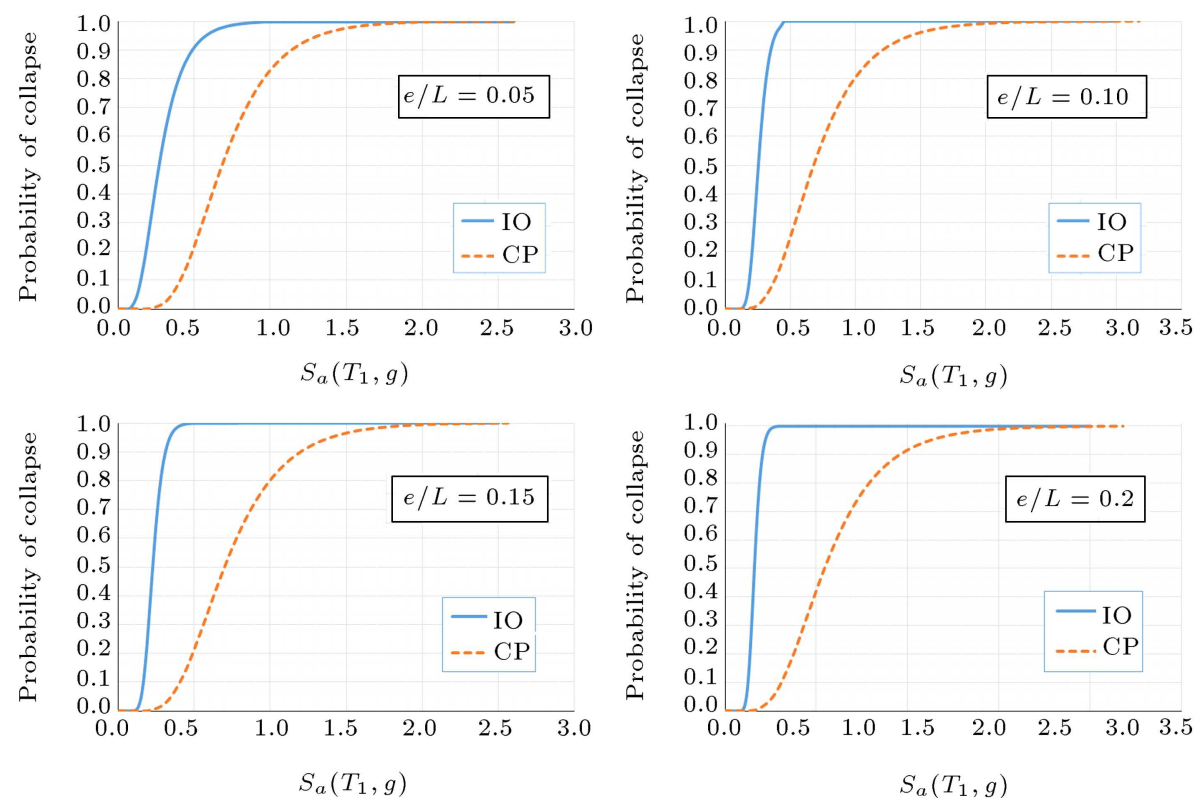

Figure 27. Fragility curves for 6-storey structure for different $e / L$.

the structure increases by decreasing its stiffness, the probability of the resonance phenomenon formation is reduced and IDA curves become more regular. Values of the response modification factor are reduced with an increase in the height of structures. The reason is the decrease in the ductility factor is due to further softening of structures by increasing their height.

Under a constant spectral acceleration, the damage probability of a structure increases with the increase of $e / L$ ratio, as well as the reduction of its height, due to the higher flexibility of the structure. The response modification factor is calculated through multiplying the overstrength factor by the ductility factor. In 6- and 10-storey structures, these two parameters have optimum values in $e / L=0.1$ due to the proper stiffness and ductility in this ratio. However, in the 2-storey structure, $e / L=0.05$ is the best because of the high overstrength factor in this ratio. The reason for this phenomenon is the resistance of the structure with low periods against the applied records. That is, the spectral acceleration needed for such structures to reach the damage level is higher than the spectral acceleration of other structures with high periods. 

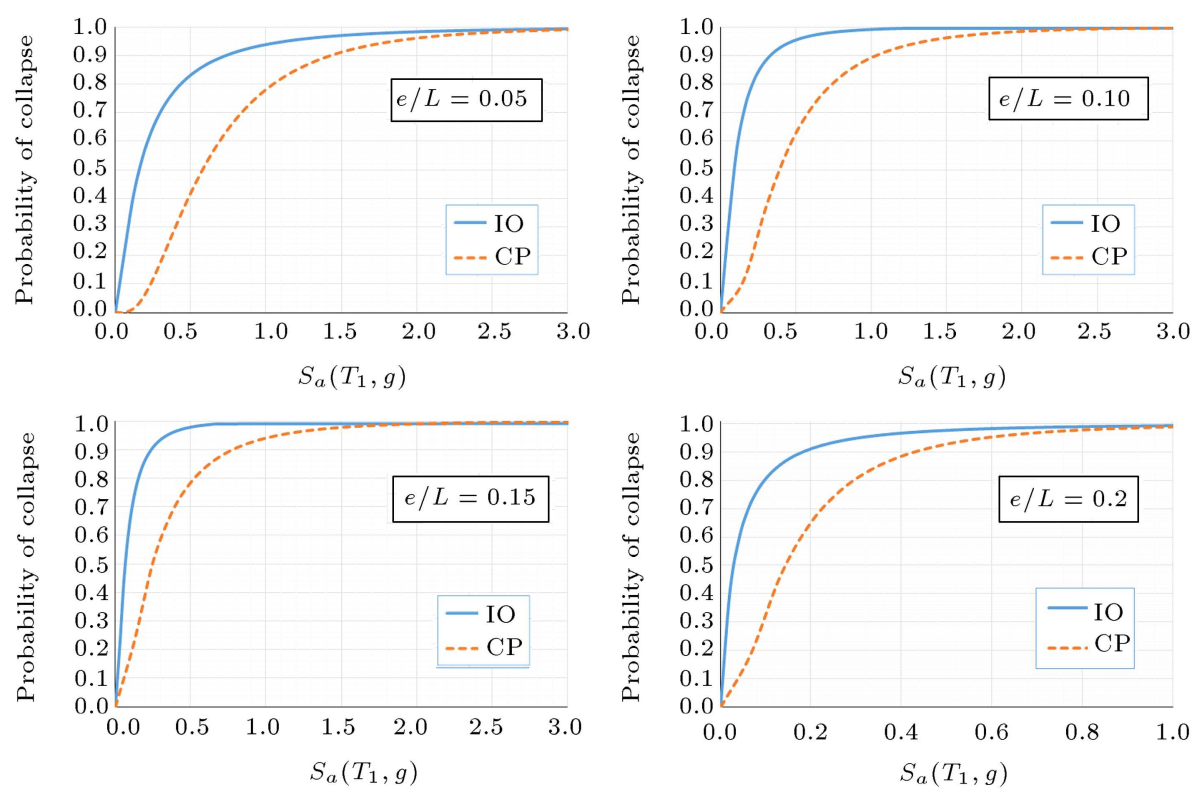

Figure 28. Fragility curves for 10-storey structure for different $e / L$.

Table 18. Mean values of overstrength, ductility and response modification factors for different frames.

\begin{tabular}{|c|c|c|c|c|c|}
\hline $\begin{array}{c}\text { Storey } \\
\text { numbers }\end{array}$ & e/L & $\boldsymbol{R}_{\mu}$ & $\boldsymbol{R}_{s}$ & $\boldsymbol{R}_{\mathrm{LRFD}}$ & $\boldsymbol{R}_{\mathrm{ASD}}$ \\
\hline \multirow{4}{*}{2} & 0.2 & 3.42 & 2.89 & 9.68 & 13.55 \\
\hline & 0.15 & 4.29 & 2.69 & 11.08 & 15.51 \\
\hline & 0.1 & 3.71 & 2.82 & 10.35 & 14.49 \\
\hline & 0.05 & 2.68 & 4.00 & 10.76 & 15.06 \\
\hline \multirow{4}{*}{6} & 0.2 & 3.30 & 2.25 & 7.78 & 10.89 \\
\hline & 0.15 & 3.48 & 2.42 & 8.52 & 11.93 \\
\hline & 0.1 & 4.33 & 1.96 & 8.58 & 12.01 \\
\hline & 0.05 & 3.68 & 1.75 & 6.58 & 9.21 \\
\hline \multirow{4}{*}{10} & 0.2 & 2.34 & 1.44 & 3.34 & 4.68 \\
\hline & 0.15 & 3.08 & 1.80 & 5.26 & 7.36 \\
\hline & 0.1 & 4.29 & 1.89 & 8.15 & 11.40 \\
\hline & 0.05 & 4.02 & 1.78 & 6.69 & 9.36 \\
\hline Mean & & 3.55 & 2.31 & 8.06 & 11.29 \\
\hline
\end{tabular}

\section{Conclusions}

The results obtained from analyses are briefly summarized as follows:

1. Considering pushover analysis curves, all structures become more flexible with the increase of $e / L$ ratio values. This stiffness reduction is more obvious in the 10-storey structure;

2. The Incremental Dynamic Analysis (IDA) curves become more regular with lower dispersion by increasing the ratio of link beam length to span length;
3. Mean values obtained for the response modification factor (corresponding to ultimate limit state), ductility and overstrength factors are 8.06, 3.55, and 2.31 , respectively;

4. The values of the response modification factor are reduced by increasing the height of the structure;

5 . The most appropriate values of $e / L$ ratio in the eccentrically split-X bracing are 0.1 for tall structures and 0.05 for small ones;

6. The damage probability increases in a constant spectral acceleration by increasing the ratio of link beam length to span length;

7. The spectral acceleration needed for creating target displacement is reduced in IDA curves by increasing the height of the structure.

\section{Nomenclature}

$\begin{array}{ll}S_{a}\left(T_{1}\right) & \text { Spectrum acceleration for first period } \\ R_{\mu} & \text { Ductility factor } \\ R_{s} & \text { Overstrength factor } \\ R_{L R F D} & \text { Response modification factor } \\ e & \text { Length of eccentrically beam } \\ L & \text { Length of spam } \\ V_{b(D y n, u)} & \text { Maximum nonlinear base shear force } \\ V_{b(D y n, e l)} & \begin{array}{l}\text { Maximum linear base shear force in } \\ \text { dynamic analysis }\end{array} \\ Y & \text { Allowable stress factor } \\ V_{y} & \text { Base shear force of yielding }\end{array}$




$\begin{array}{ll}V_{s} & \begin{array}{l}\text { Base shear force of first point of } \\ \text { Yielding }\end{array} \\ V_{w} & \begin{array}{l}\text { Code limitation of base shear } \\ D_{S i}\end{array} \\ & \begin{array}{l}\text { Occurrence probability of damage } \\ \text { status }\end{array} \\ & \begin{array}{l}\text { Standard accumulative lognormal } \\ \text { distribution function }\end{array} \\ & \begin{array}{l}\text { Spectral acceleration with lognormal } \\ \text { distribution }\end{array} \\ \lambda \text { and } \beta & \text { Average and standard deviation of ln } x\end{array}$

\section{References}

1. Roeder, C.W. and Popov, E.P. "Inelastic behaviour of eccentrically braced steel frames under cyclic loadings", Report no. UCB/EERC-77/18, Berkeley (CA): Earthquake Engineering Research Center (1977).

2. Hjelmstad, K.D. and Popov, E.P. "Seismic behaviour of active beam links in eccentrically braced frames", Report no. UCB/EERC-83/15, Berkeley (CA): Earthquake Engineering Research Institute (1983).

3. Malley, J.O. and Popov, E.P. "Design considerations for shear links in eccentrically braced frames", Report no. UCB/EERC-83/24, Berkeley (CA): Earthquake Engineering Research Institute (1983).

4. Kasai, K. and Popov, E.P. "A study of seismically resistant eccentrically braced frame systems", Report no. UCB/EERC-86/01, Berkeley (CA): Earthquake Engineering Research Institute (1986).

5. Ricles, J.M. and Popov, E.P. "Experiments on eccentrically braced frames with composite floors", Report no. UCB/EERC-87/06, Berkeley (CA): Earthquake Engineering Research Institute (1987).

6. Engelhardt, M.D. and Popov, E.P. "Behaviour of long links in eccentrically braced frames", Report no. UCB/EERC-89/01, Berkeley (CA): Earthquake Engineering Research Institute (1989).

7. Foutch, D.A., Goel, S., and Roeder, C.W. "Seismic testing of full-scale steel building, part I", Journal of Structural Engineering, ASCE, 113(11), pp. 21112129 (1987).

8. Roeder, C.W., Foutch, D.A., and Goel, S.C. "Seismic testing of full-scale steel building, part II", Journal of Structural Engineering, ASCE, 113(11), p. 21936 (1987).

9. Whittaker, A.S., Uang, C.M., and Bertero, V.V. "Earthquake simulation tests and associated studies of a 0.3 -scale model of a six-story eccentrically braced steel structure", Report no. UCB/EERC87/02, Berkeley (CA): Earthquake Engineering Research Center, University of California (1987).

10. Itani, A.M. "Cyclic behaviour of Richmond-San Rafael tower links", Report no. CCEER 97-4. Reno (NV): Center for Civil Engineering Earthquake Research, University of Nevada at Reno (1997)
11. Dusicka, P. "Built-up shear links as energy dissipators for seismic protection of bridges", Ph.D. Dissertation. Reno (NV): Department of Civil and Environmental Engineering, University of Nevada (2004).

12. McDaniel, C.C. , Uang, C.M., and Seible, F., Cyclic Testing of Suspension Tower Shear Links of the San Francisco ( $C A$ ), Department of Structural Engineering, University of California (2002).

13. Arce, G. "Impact of higher strength steels on local buckling and overstrength of links in eccentrically braced frames", M.S. Thesis, Austin (TX): Department of Civil, Architectural and Environmental Engineering, The University of Texas at Austin (2002).

14. Galvez, P. "Investigation of factors affecting web fractures in shear links", M.S. Thesis, Austin (TX): Department of Civil, Architectural and Environmental Engineering, The University of Texas at Austin (2004).

15. Ryu, H.C. "Effects of loading history on the behaviour of links in seismic-resistant eccentrically braced frames", M.S. Thesis, Austin (TX): Department of Civil, Architectural and Environmental Engineering, The University of Texas at Austin (2005).

16. Okazaki, T. "Seismic performance of link-to-column connections in steel eccentrically braced frames", Ph.D. Dissertation. Austin (TX): Department of Civil, Architectural and Environmental Engineering, The University of Texas at Austin (2004).

17. Okazaki, T., Arec, G., Ryu, H.C., and Engelhardt, M.D. "Experimental study of local buckling, overstrength and fracture of links in eccentrically braced frames", Journal of Structural Engineering, 131(10), pp. $1526-1535$ (2005).

18. Chao, S.H., Khandelwal, K., and Sherif, E.T. "Ductile web fracture initiation in steel shear links", Journal of Structural Engineering, 132(8), pp. 1192-1200 (2006).

19. Rossi, P.P. and Lombardo, A. "Influence of link overstrength factor on seismic behaviour of eccentrically braced frame", Journal of Structural Engineering, 63(11), pp. 1529-1545 (2007).

20. Ozhendekci, D. and Ozhendekci, N. "Effects of the frame geometry on the weight and inelastic behaviour of eccentrically braced chevron steel frames", Journal of Constructional Steel Research, 64(3), pp. 326-343 (2008).

21. Chegeni, B. and Mohebkhah, A. "Rotation capacity improvement of long link beams in eccentrically braced frames", Scientia Iranica, 21(3), pp. 516-524 (2014).

22. Kurdi, K., Budiono, B., Moestopo, M., Kusumastuti, D., and Refai Muslih, M. "Residual stress effect on link element of eccentrically braced frame", Journal of Constructional Steel Research, 128(1), pp. 397-404 (2017). 
23. Ming, L. and Mingzhou, S. "Seismic performance of high-strength steel fabricated eccentrically braced frame with vertical shear link", Journal of Constructional Steel Research, 137(10), pp. 262-285 (2017).

24. Tian, X., Su, M., Lian, M., Wang, F., and Li, S. "Seismic behavior of K-shaped eccentrically braced frames with high-strength steel, Shaking table testing and FEM analysis", Journal of Constructional Steel Research, 143(4), pp. 250-263 (2018).

25. Bosco, M. and Rossi, P.P. "Seismic behaviour of eccentrically braced frames", Engineering Structures, 31(3), pp. 664-674 (2008).

26. Brunesi, E., Nascimbene, R., and Casagrande, L. "Seismic analysis of high-rise mega-braced frame-core buildings", Engineering Structures, 115, pp. 1-17 (2016).

27. Bosco, M., Marino, E.M., and Rossi, P.P. "Influence of modelling of steel link beams on the seismic response of EBFs", Engineering Structures, 127, pp. 459-474 (2016).

28. AISC, Seismic Provisions for Structural Steel Buildings (ANSI/AISC 341-05) Chicago (IL): American Institute of Steel Construction, Inc (2005).

29. Vamvatsikos, D. and Cornell, C.A. "The incremental dynamic analysis and its application to performancebased earthquake engineering", 12th European Conference on Earthquake Engineering, p. 479 (2002).

30. Uang, C.M. "Establishing R (or Rw) and Cd factor for building seismic provision", Journal of Structure Engineering, 117(1), pp. 19-28 (1991).

31. Zahrai, S.M. and Jalali, M. "Experimental and analytical investigations on seismic behavior of ductile steel knee braced frames", Steel and Composite Structures, Journal, 16(1), pp. 1-21 (2014).

32. Mwafy, A.M. and Elnashai, A.S. "Calibration of force reduction factors of RC buildings", Journal of Earthquake Engineering, 6(22), pp. 239-273 (2002).

33. Vamvatsikos, D. and Cornell, C.A. "Incremental dynamic analysis", Earthquake Engineering and Structural Dynamics, 31(3), pp. 491-514 (2003).

34. ASCE/SEI 7-10, Minimum Design Loads for Buildings and Other Structures, Reston, Virginia: American Society of Civil Engineers (ASCE) (2010).

35. OpenSees, Command Language, Incremental Dynamic Analysis, Earthquake Engineering, http://opensees. berkeley.edu/ (2003).

36. Rozon, J., Koboevic, S., and Tremblay, R. "Study of behaviour of eccentrically braced frames in response to seismic loads", The 14th World Conference on Earthquake Engineering, October 12-17, Beijing, China (2008).
37. Gulec, C.K., Gibbons, B., Chen, A., and Whittaker, A.S. "Damage states and fragility functions for link beams in eccentrically braced frames", Journal of Constructional Steel Research, 67(9), pp. 1299-1309 (2011).

38. Jalayer, F. and Cornell, C.A. "A technical framework for probability-based demand and capacity factor design", Pacific Earthquake Engineering Research Center PEER Rep. 2003/8, PEER Berkeley, Calif. (2003)

39. Ellingwood, B.R. and Tekie, P.B. "Seismic fragility assessment of concrete gravity dams", Earthquake Engineering and Structural Dynamics, 32(14), pp. 22212240 (2003).

40. Wen, Y.K., Ellingwood, B.R., and Bracci, J. "Vulnerability function framework for consequence-based engineering", MAE Center Project DS-4 Report, April 28,44 . (2004).

41. ASCE, American Society of Civil Engineers, Seismic Rehabilitation of Existing Buildings, ASCE/SEI 41-06 (2007).

\section{Biographies}

Ramin Sheikhi Garjan received his BS and MS degrees in Civil Engineering, respectively, from the Department of Civil Engineering at the University of Mohaghegh Ardabili, Ardebil, Iran and K. N. Toosi University of Technology, Tehran, Iran. He graduated in 2016. His field of research includes EBF seismic behaviour, incremental dynamic analysis, steel structures and fragility curves.

Nader Fanaie obtained his BS, MS and $\mathrm{PhD}$ degrees in Civil Engineering from the Department of Civil Engineering at Sharif University of Technology, Tehran, Iran. He graduated in 2008 and, at present, is a faculty member of $\mathrm{K}$. N. Toosi University of Technology, Tehran, Iran. He has supervised 30 MS theses up to now. His field of research includes seismic hazard analysis, earthquake simulation, seismic design and IDA. He has published 52 journal and conference papers, and also 10 books. He received 3rd place in the first mathematical competition, held at Sharif University of Technology, in 1996, and a Gold Medal in "The 4th Iranian Civil Engineering Scientific Olympiad" in 1999. In 2001, he achieved first place in the PhD scholarship abroad exam. He was also acknowledged as an innovative engineer on 'Engineering Day', in 2008. 